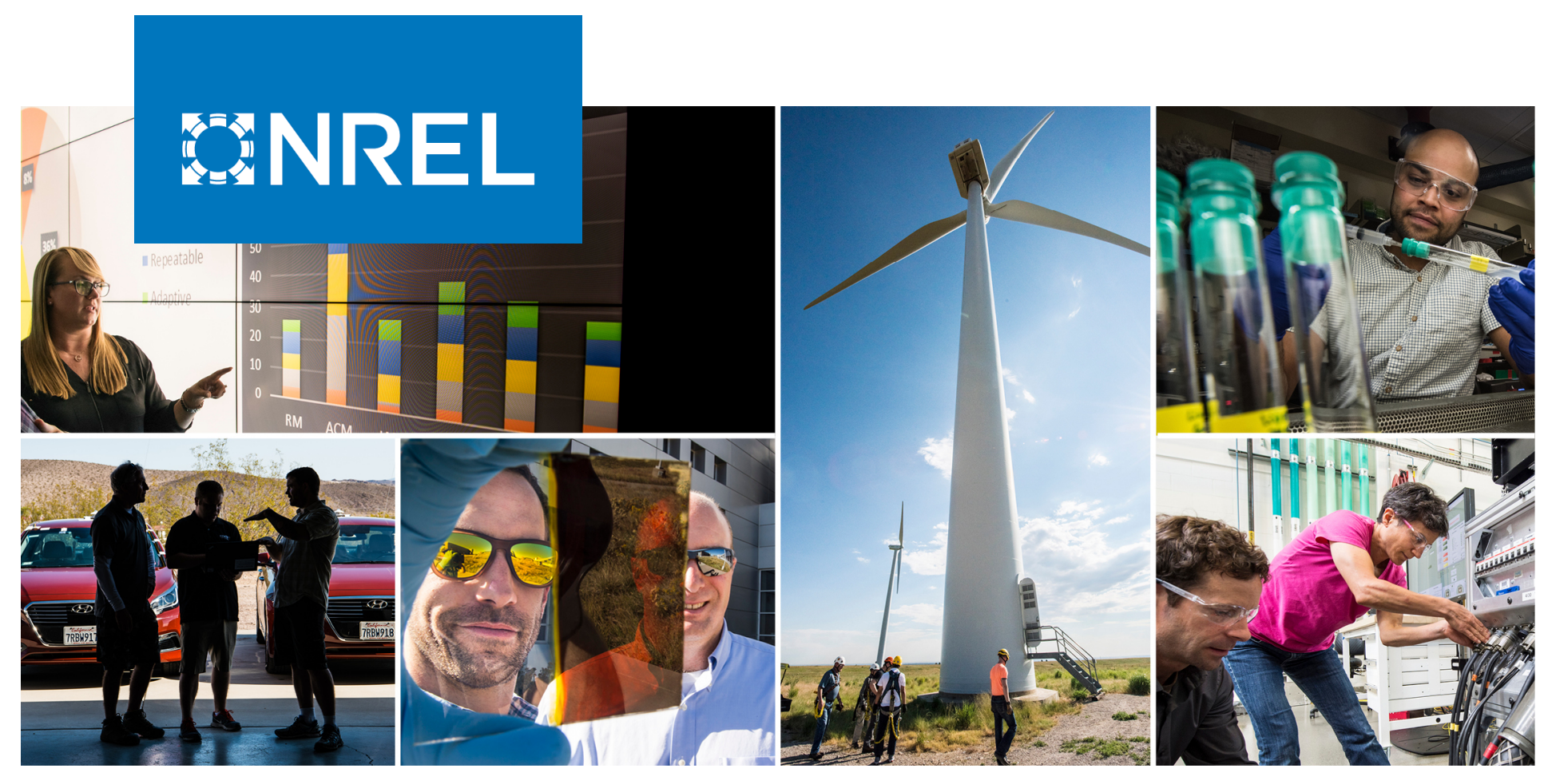

\title{
Marine Energy in the United States: An Overview of Opportunities
}

Levi Kilcher, Michelle Fogarty, and Michael Lawson

National Renewable Energy Laboratory

NREL is a national laboratory of the U.S. Department of Energy

Office of Energy Efficiency \& Renewable Energy

Operated by the Alliance for Sustainable Energy, LLC

This report is available at no cost from the National Renewable Energy Laboratory (NREL) at www.nrel.gov/publications.
Technical Report

NREL/TP-5700-78773

February 2021 


\title{
GNREL
}

\section{Marine Energy in the United States: An Overview of Opportunities}

\author{
Levi Kilcher, Michelle Fogarty, and Michael Lawson
}

National Renewable Energy Laboratory

\section{Suggested Citation}

Kilcher, Levi, Michelle Fogarty, and Michael Lawson. 2021. Marine Energy in the United States: An Overview of Opportunities. Golden, CO: National Renewable Energy Laboratory. NREL/TP-5700-78773. https://www.nrel.gov/docs/fy21osti/78773.pdf.

NREL is a national laboratory of the U.S. Department of Energy Office of Energy Efficiency \& Renewable Energy Operated by the Alliance for Sustainable Energy, LLC

This report is available at no cost from the National Renewable Energy Laboratory (NREL) at www.nrel.gov/publications.

Contract No. DE-AC36-08GO28308
Technical Report

NREL/TP-5700-78773

February 2021

National Renewable Energy Laboratory 15013 Denver West Parkway Golden, CO 80401

303-275-3000 • www.nrel.gov 


\section{NOTICE}

This work was authored by the National Renewable Energy Laboratory, operated by Alliance for Sustainable Energy, LLC, for the U.S. Department of Energy (DOE) under Contract No. DE-AC36-08G028308. Funding provided by U.S. Department of Energy Office of Energy Efficiency and Renewable Energy Water Power Technologies Office. The views expressed herein do not necessarily represent the views of the DOE or the U.S. Government.

This report is available at no cost from the National Renewable Energy Laboratory (NREL) at www.nrel.gov/publications.

U.S. Department of Energy (DOE) reports produced after 1991 and a growing number of pre-1991 documents are available free via www.OSTI.gov.

Cover Photos by Dennis Schroeder: (clockwise, left to right) NREL 51934, NREL 45897, NREL 42160, NREL 45891, NREL 48097, NREL 46526.

NREL prints on paper that contains recycled content. 


\section{Acknowledgments}

This report is primarily a summary of work completed by leading marine energy scientists. It would not have been possible without the work they put into the original marine energy resource assessments. It was authored by the National Renewable Energy Laboratory, operated by Alliance for Sustainable Energy, LLC, for the U.S. Department of Energy (DOE) under Contract No. DE-AC36-08GO28308. Funding provided by U.S. Department of Energy, Office of Energy Efficiency and Renewable Energy, Water Power Technologies Office.

The authors thank the DOE's Water Power Technologies Office team for its timely, thorough, and insightful review of this work. Hoyt Battey, in particular, provided considerable encouragement and valuable perspective.

We also thank the National Research Council's review of the assessments; many of their recommendations were implemented here and helped frame this report. We are also grateful to our colleagues, Zhaoqing Yang and Vince Neary, for their careful review and input. We thank Terri Marshburn for her steadfast review and support in keeping this publication moving forward efficiently. We also thank John Frenzl for his creative and detailed presentation of the results in Figure ES-1, which provides a compact and lustrous overview of the results contained herein. Finally, we thank the numerous anonymous reviewers who took the time to provide detailed and thoughtful comments that provided many important, detailed, and nuanced contributions. 


\section{List of Acronyms}

CONUS

DOE

EEZ

IEC

$\mathrm{kWh}$

GW

MHK

MW

nmi

NREL

NRC

OTEC

PNNL

QTR

Sandia

TWh contiguous U.S. states

U.S. Department of Energy

exclusive economic zone

International Electrotechnical Commission

kilowatt hour

gigawatt

marine and hydrokinetic

megawatt

nautical mile

National Renewable Energy Laboratory

National Research Council

ocean thermal energy conversion

Pacific Northwest National Laboratory

2015 Quadrennial Technology Review

Sandia National Laboratories

terawatt hour 


\section{Executive Summary}

This report provides a concise and consolidated overview of the Unites States' marine energy resources. ${ }^{1}$ The results reported herein are primarily based on U.S. Department of Energy (DOE)-funded marine energy resource assessments in the following technology areas: wave, tidal currents, ocean currents, ocean thermal gradients, and river currents (Jacobson, Hagerman, and Scott 2011; Haas et al. 2011; Haas 2013; Ascari et al. 2012). This report also incorporates recent updates and refinements to the U.S. wave and tidal resource assessments performed by several national laboratories (Kilcher, Garcia-Medina, and Yang 2021; Kilcher, Haas, and Muscalus 2021). Many of these refinements were undertaken to address feedback from the National Research Council's evaluation of the original resource assessments (National Research Council 2013). Further, this report refines the analysis published to date by identifying the marine energy resources available in each state or region to the extent practical. In short, this report summarizes the best available data on U.S. marine energy resources at the state, regional, and national scales.

While marine energy technologies are still at the relatively early stages of development, the resource potential is immense and distributed widely across the nation's coastlines and rivers. We use the following definitions to frame the conversation about marine energy resource potentials (International Electrotechnical Commission 2020):

- Theoretical resource - the energy available in the resource

- Technical resource - the proportion of the theoretical resource that can be captured using existing technology options

- Practical resource - the proportion of the technical resource that is available after consideration of external constraints. Where 'external constraints' are the socioeconomic, environmental, regulatory, and other competing-use constraints that determine whether a project is viable at a specific site.

In this work, we focus on the technical resource within the nation's exclusive economic zone $(\mathrm{EEZ})^{2}$ that can be harnessed for large-scale (megawatt- to gigawatt-scale) energy generation. It does not include marine energy resources that may be valuable to many blue economy applications, ${ }^{3}$ which often have lower power requirements and can use low-energy marine energy resources that are not sufficiently energetic for large-scale energy generation. Accordingly, some locations where this report indicates there is little or no technical resource

\footnotetext{
${ }^{1}$ Marine energy is defined in the Energy Act of 2020 as energy from waves, tides, ocean currents, free-flowing rivers and man-made channels, as well as from differentials in salinity, temperature, and pressure $\left(116^{\text {th }}\right.$ U.S. $^{\text {. }}$ Congress 2020). Before this bill was enacted, marine energy had often been known as marine and hydrokinetic energy (MHK).

${ }^{2}$ In this report, we use the National Oceanic and Atmospheric Administration definition of the U.S. EEZ (National Oceanic and Atmospheric Administration 2019).

${ }^{3}$ Blue economy applications for marine energy include providing power at sea to support offshore industries, science, and security activities and also meeting the energy and water needs of coastal and rural island communities (LiVecchi et al. 2019).
} 
may still have marine energy resources that are sufficient to provide power for blue economy applications.

The total marine energy technical resource in the 50 states is $2,300 \mathrm{TWh} / \mathrm{yr}$, equivalent to $57 \%$ of the electricity generated by those states in 2019. The nation's Pacific and Caribbean territories and freely associated states add an additional 4,100 TWh/yr of ocean thermal energy resource. While we do not attempt to forecast the future deployment of marine energy technologies, it is important to note that even if only a small portion of the technical resource potential is captured, marine energy technologies would make significant contributions to our nation's energy needs. For example, utilizing just one-tenth of the technically available marine energy resources in the 50 states would equate to $5.7 \%$ of our nation's current electricity generation - enough energy to power 22-million homes (U.S. Energy Information Administration 2020) (Figure ES-1). Assuming this energy could be generated at capacity factors between $30 \%$ and $70 \%$, this would translate to between $40 \mathrm{GW}$ and $90 \mathrm{GW}$ of marine energy projects.

Marine energy resources are distributed throughout the United States and provide unique opportunities to different states and regions. Massive quantities of wave energy arrive at our coastlines every year, and this resource is particularly energetic along the nation's Pacific shorelines (California, Oregon, Washington, Alaska, and Hawaii). Tidal energy, perhaps the most predictable renewable energy resource, could play a major role in Alaska's electricity generation and could realistically contribute sizable quantities of power in Washington state and several Atlantic states. Ocean current energy, which is primarily contained in the Gulf Stream, has the potential to provide steady, reliable power to homes in North Carolina, South Carolina, Georgia, and Florida. Ocean thermal energy is another significant opportunity for parts of the Atlantic coast as well as the Gulf Coast states, Hawaii, and U.S. Pacific territories and freely associated states. Finally, the nation's riverine resource can be harnessed without the need for dams or river diversion to provide reliable power throughout the country. 


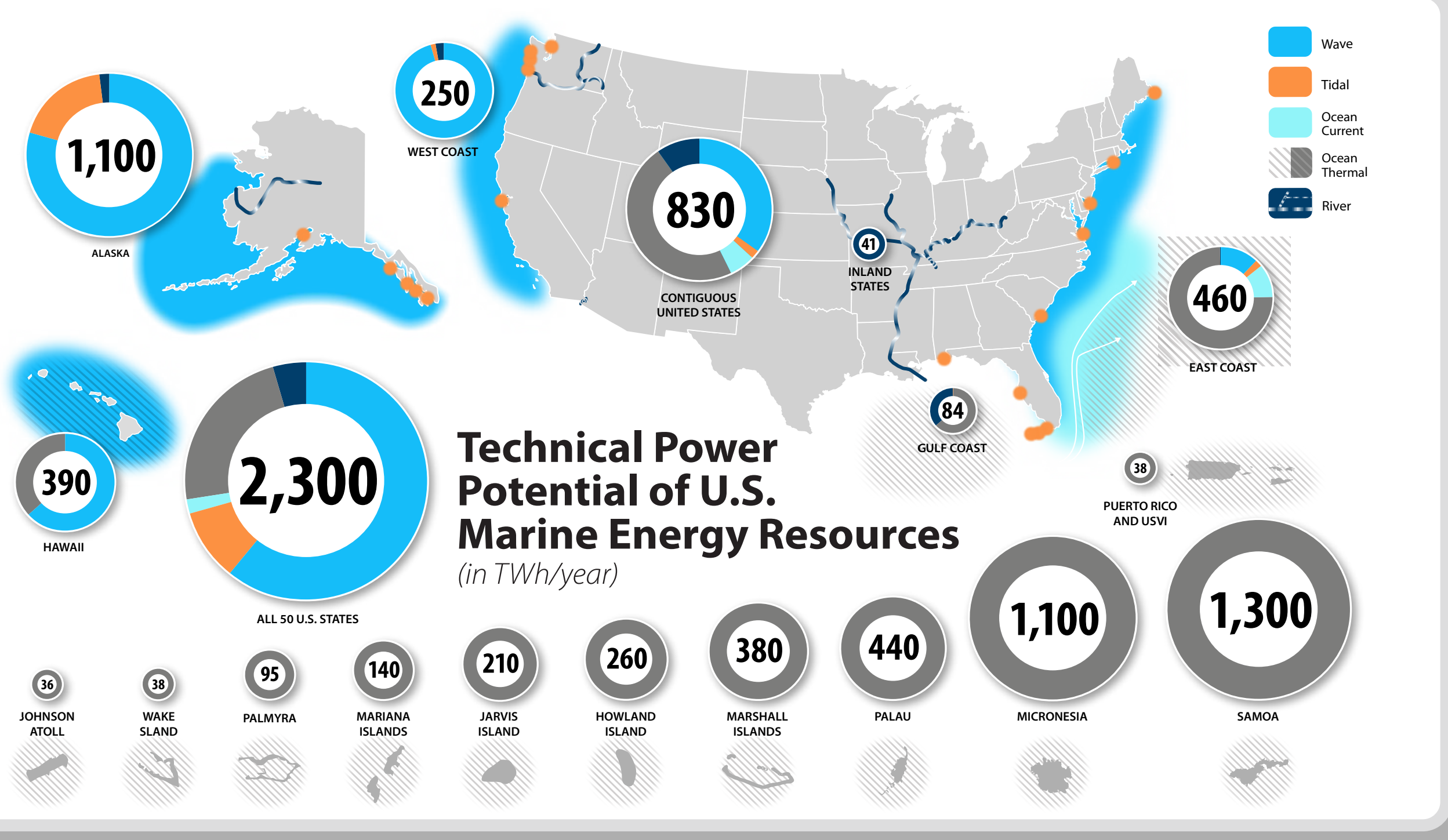

\begin{tabular}{|l|r|r|r|}
\begin{tabular}{|l|l|} 
U.S. States \\
a
\end{tabular} & $\begin{array}{r}\text { Technical Resource } \\
(\text { TWh/yr) }\end{array}$ & $\begin{array}{r}\text { Potential Number } \\
\text { of Homes Powered }\end{array}$ & $\begin{array}{r}\text { Resource as a Percent } \\
\text { of U.S. Electricity } \\
\text { Generation (\%) }\end{array}$ \\
\hline Wave (to EEZ) & 1,400 & $130,000,000$ & 34 \\
\hline Tidal & 220 & $21,000,000$ & 5.4 \\
\hline Ocean Current & 49 & $4,600,000$ & 1.2 \\
\hline Ocean Thermal & 540 & $51,000,000$ & 13 \\
\hline River & 99 & $9,300,000$ & 2.4 \\
\hline Total & $\mathbf{2 , 3 0 0}$ & $\mathbf{2 2 0 , 0 0 0 , 0 0 0}$ & $\mathbf{5 7}$ \\
\hline
\end{tabular}

${ }^{a}$ All values are listed to two significant figures; therefore, totals shown may not equal the sum of values.

${ }^{b}$ Detailed methodologies for estimating Technical Resource are provided in Section 2 of the report.

'Based on avg. monthly household electricity use of $877 \mathrm{kWh} /$ month-or 10,649 kWh in 2019.

epercent based on all 50 U.S. states' electricity generation $(4,126.7$ TWh) in 2019.

\begin{tabular}{|c|c|c|c|c|}
\hline East Coast & $\begin{array}{l}\text { Technical } \\
\text { Resource } \\
(\mathrm{TWh} / \mathrm{yr})^{\mathrm{b}}\end{array}$ & $\begin{array}{l}\text { Potential Number } \\
\text { of Homes Powered }\end{array}$ & $\begin{array}{r}\text { Resource as a Percent } \\
\text { of Regional Electricity } \\
\text { Generation (\%) }\end{array}$ & $\begin{array}{r}\text { Resource as a Percent } \\
\text { of U.S. Electricity } \\
\text { Generation (\%) }\end{array}$ \\
\hline Wave (to EEZ) & 55 & $5,200,000$ & 6.0 & 1.3 \\
\hline Tidal & 10 & 950,000 & 1.1 & 0.24 \\
\hline Ocean Current & 49 & $4,600,000$ & 5.3 & 1.2 \\
\hline Ocean Thermal & 340 & $32,000,000$ & 37 & 8.3 \\
\hline River & 0.67 & 63,000 & 0.07 & 0.02 \\
\hline Total & 460 & $43,000,000$ & 49 & 11 \\
\hline
\end{tabular}

dPercent based on 924.5 TWh of the East Coast's electricity generation produced in 2019. (ME to FL with 1/2 of FL's generation.) 


\begin{tabular}{|c|c|c|c|c|}
\hline Alaska ${ }^{a}$ & $\begin{array}{l}\text { Technical } \\
\text { Resource } \\
\text { (TWh/yr) }^{b}\end{array}$ & $\begin{array}{r}\text { Potential } \\
\text { Number of } \\
\text { Homes Powered }\end{array}$ & $\begin{array}{r}\text { Resource as a Percent } \\
\text { of Regional Electricity } \\
\text { Generation (\%) }\end{array}$ & $\begin{array}{r}\text { Resource as a Percent } \\
\text { of U.S. Electricity } \\
\text { Generation (\%) }\end{array}$ \\
\hline Wave (to EEZ) & 890 & $83,000,000$ & 15,000 & 21 \\
\hline Tidal & 210 & $20,000,000$ & 3,400 & 5.0 \\
\hline Ocean Current & 0 & 0 & 0 & 0 \\
\hline Ocean Thermal & 0 & 0 & 0 & 0 \\
\hline River & 21 & $1,900,000$ & 340 & 0.50 \\
\hline Total & 1,100 & $100,000,000$ & 18,000 & 27 \\
\hline
\end{tabular}

dPercent based on 6.1 TWh of Alaska's electricity generation produced in 2019.

\begin{tabular}{|c|c|c|c|c|}
\hline West Coast ${ }^{a}$ & $\begin{array}{l}\text { Technical } \\
\text { Resource } \\
(\mathrm{TWh} / \mathrm{yr})^{\mathrm{b}}\end{array}$ & $\begin{array}{r}\text { Potential } \\
\text { Number of } \\
\text { Homes Powered }\end{array}$ & $\begin{array}{r}\text { Resource as a Percent } \\
\text { of Regional Electricity } \\
\text { Generation (\%) }\end{array}$ & $\begin{array}{r}\text { Resource as a Percent } \\
\text { of U.S. Electricity } \\
\text { Generation (\%) }\end{array}$ \\
\hline Wave (to EEZ) & 240 & $22,000,000$ & 64 & 5.7 \\
\hline Tidal & 4.1 & 380,000 & 1.1 & 0.10 \\
\hline Ocean Current & 0 & 0 & 0 & 0 \\
\hline Ocean Thermal & 0 & 0 & 0 & 0 \\
\hline River & 6.7 & 630,000 & 1.8 & 0.16 \\
\hline Total & 250 & $23,000,000$ & 67 & 6.0 \\
\hline
\end{tabular}

dPercent based on 370.5 TWh of the West Coast's electricity generation produced in 2019.

\begin{tabular}{|c|c|c|c|c|}
\hline Hawaiia & $\begin{array}{l}\text { Technical } \\
\text { Resource } \\
(\mathrm{TWh} / \mathrm{yr})^{b}\end{array}$ & $\begin{array}{r}\text { Potential } \\
\text { Number of } \\
\text { Homes Powered }\end{array}$ & $\begin{array}{r}\text { Resource as a Percent } \\
\text { of Regional Electricity } \\
\text { Generation (\%) }\end{array}$ & $\begin{array}{r}\text { Resource as a Percent } \\
\text { of U.S. Electricity } \\
\text { Generation (\%) }\end{array}$ \\
\hline Wave (to EEZ) & 250 & $23,000,000$ & 2,500 & 6.0 \\
\hline Tidal & not assessed & & & \\
\hline Ocean Current & 0 & 0 & 0 & 0 \\
\hline Ocean Thermal & 140 & $13,000,000$ & 1,500 & 3.5 \\
\hline River & not assessed & & & \\
\hline Total & 390 & $37,000,000$ & 4,000 & 9.4 \\
\hline
\end{tabular}

dPercent based on 9.7 TWh of Hawaii's electricity generation produced in 2019.

\section{Pacific Territories}

and Freely

Associated States ${ }^{a}$

Wave (to EEZ)

Tidal

Ocean Current

Ocean Thermal

- River

Total

All values are listed to two significant figures; therefore, totals shown may not equal the sum of values.

Detailed methodologies for estimating Technical Resource are provided in Section 2 of the report.

'Based on avg. monthly household electricity use of $877 \mathrm{kWh} /$ month-or 10,649
Technical Potential Resource as a Percent of of Regional Electricity

Resource as a Percent of U.S. Electricity Generation (\%)

U.S. States ${ }^{\mathrm{a}} \quad(\mathrm{TWh} / \mathrm{yr})^{\mathrm{b}}$ Homes Powered ${ }^{\mathrm{c}} \quad$ Generation (\%)

Wave (to EEZ)

Tidal

Ocean Current

Ocean Thermal

River

$41 \quad 3,800,000$

$413,800,000$

0.99

'Percent based on 1,901.0 TWh of the inland U.S. states' electricity generation produced in 2019.

\begin{tabular}{|c|c|c|c|c|}
\hline Gulf Coast $^{\mathrm{a}}$ & $\begin{array}{l}\text { Technical } \\
\text { Resource } \\
(\mathrm{TWh} / \mathrm{yr})^{\mathrm{b}}\end{array}$ & $\begin{array}{r}\text { Potential } \\
\text { Number of } \\
\text { Homes Powered }\end{array}$ & $\begin{array}{r}\text { Resource as a Percent } \\
\text { of Regional Electricity } \\
\text { Generation }(\%)^{d}\end{array}$ & $\begin{array}{r}\text { Resource as a Percent } \\
\text { of U.S. Electricity } \\
\text { Generation (\%) }\end{array}$ \\
\hline Wave (to EEZ) & 0 & 0 & 0 & 0 \\
\hline Tidal & 0.37 & 35,000 & 0.04 & 0.01 \\
\hline Ocean Current & 0 & 0 & 0 & 0 \\
\hline Ocean Thermal & 53 & $5,000,000$ & 5.8 & 1.3 \\
\hline River & 31 & $2,900,000$ & 3.3 & 0.74 \\
\hline Total & 84 & $7,900,000$ & 9.2 & 2.0 \\
\hline
\end{tabular}

'Percent based on 914.8 TWh of the Gulf Coast's electricity generation produced in 2019. (AL, LA, MS, TX, and with 1/2 of FL's generation.)

\begin{tabular}{|c|c|c|c|c|}
\hline PR \& USVIa & $\begin{array}{l}\text { Technical } \\
\text { Resource } \\
\text { (TWh/yr) }^{\text {b }}\end{array}$ & $\begin{array}{r}\text { Potential } \\
\text { Number of } \\
\text { Homes Powered }\end{array}$ & $\begin{array}{r}\text { Resource as a Percent } \\
\text { of Regional Electricity } \\
\text { Generation }(\%)^{d}\end{array}$ & $\begin{array}{r}\text { Resource as a Percent } \\
\text { of U.S. Electricity } \\
\text { Generation (\%) }\end{array}$ \\
\hline Wave (to EEZ) & 0 & 0 & 0 & 0 \\
\hline Tidal & not assessed & & & \\
\hline Ocean Current & not assessed & & & \\
\hline Ocean Thermal & 38 & $3,600,000$ & 210 & 0.92 \\
\hline River & not assessed & & & \\
\hline Total & 38 & $3,600,000$ & 210 & 0.92 \\
\hline
\end{tabular}

'Percent based on 18 TWh of Puerto Rico and the U.S. Virgin Islands' electricity generation produced in 2017.

Ocean Thermal in Pacific

Territories and Freely Technical

Resource Potential Number Resource as a Percent

Associated States ${ }^{\mathrm{a}} \quad(\mathrm{TWh} / \mathrm{yr})^{\mathrm{b}}$ of Homes Powered ${ }^{\mathrm{c}} \quad \mathrm{C}^{2}$

Johnson Atoll

Wake Island

Palmyra

Mariana Islands

Jarvis Island

Howland Island

Marshall Islands

Palau

Micronesia

Samoa

$(\mathrm{TWh} / \mathrm{yr})^{\mathrm{b}}$

Generation (\%)

Total

4,100

0.87
0.92
2.3
3.3
5.2
6.3
9.2
11
27
32
98

Figure ES-1. Technical power potential of U.S. marine energy resources (in TWh/yr) for the United States, U.S. territories, and freely associated states. 


\section{Table of Contents}

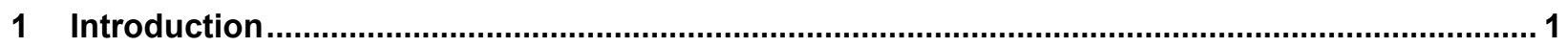

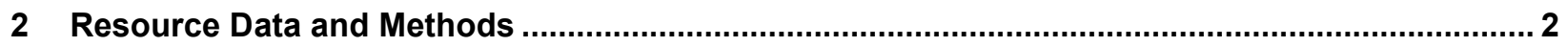

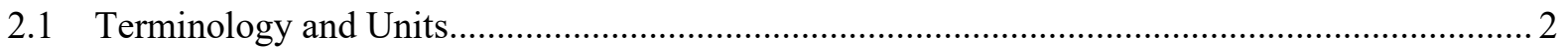

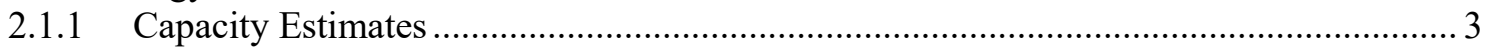

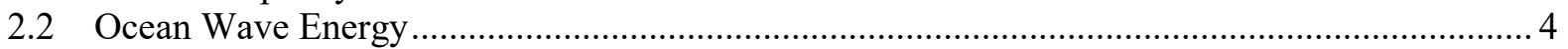

2.2.1 Ocean Wave Energy: Challenges and Future Work .................................................... 6

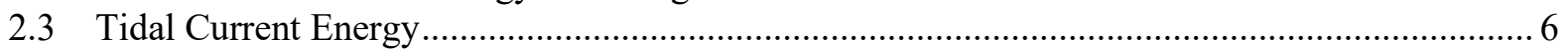

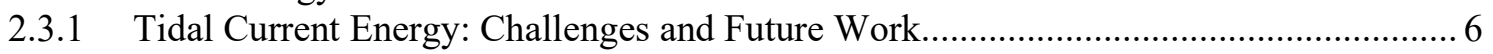

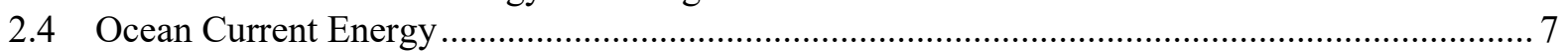

2.4.1 Ocean Current Energy: Challenges and Future Work ............................................. 8

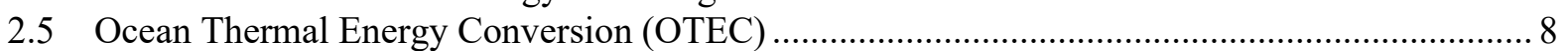

2.5.1 Ocean Thermal Energy: Challenges and Future Work .............................................. 9

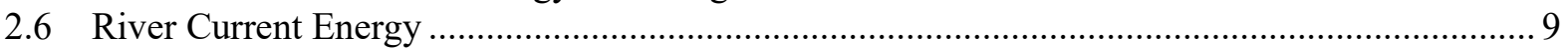

2.6.1 River Current Energy: Challenges and Future Work ............................................... 10

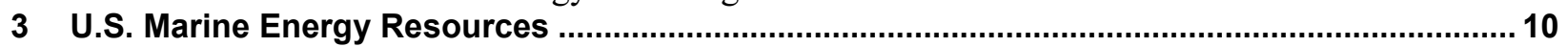

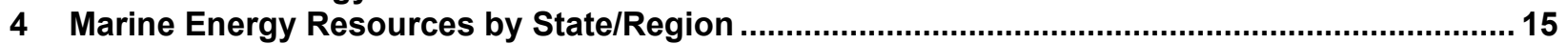

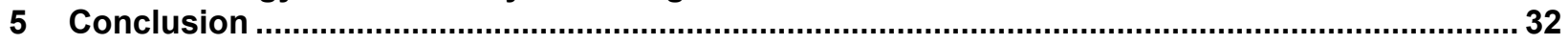

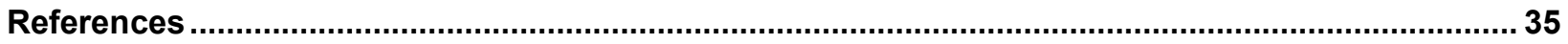

\section{List of Figures}

Figure ES-1. Technical power potential of U.S. marine energy resources (in TWh/yr) for the United

States, U.S. territories, and freely associated states. .......................................................................iii

Figure 1. Classification of marine energy resource assessment................................................................. 2

\section{List of Tables}

Table 1. Capacity Factors for Each Resource Type............................................................................... 4

Table 2a. Theoretical and Technical Marine Energy Resources for the CONUS ${ }^{\mathrm{a}}$.................................. 12

Table 2b. Theoretical and Technical Marine Energy Resources for All U.S. States ${ }^{\mathrm{a}}$............................... 13

Table 2c. Theoretical and Technical Marine Energy Resources for All U.S. States, Territories, and

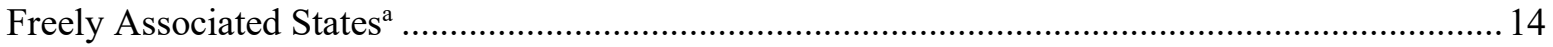

Table 3a. Theoretical and Technical West Coast Marine Energy Resources for California ${ }^{\mathrm{a}}$...................... 16

Table 3b. Theoretical and Technical West Coast Marine Energy Resources for Oregon ${ }^{\mathrm{a}}$........................ 17

Table 3c. Theoretical and Technical West Coast Marine Energy Resources for Washington a .................. 18

Table 3d. Theoretical and Technical West Coast Marine Energy Resources for the U.S. West Coast

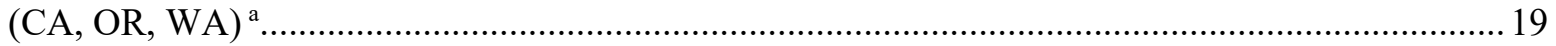

Table 4a. Theoretical and Technical East Coast Marine Energy Resources for the New England

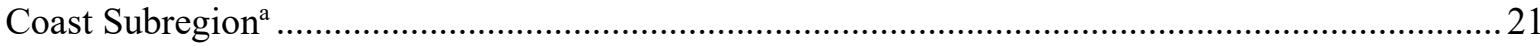

Table 4b. Theoretical and Technical East Coast Marine Energy Resources for the Mid-Atlantic

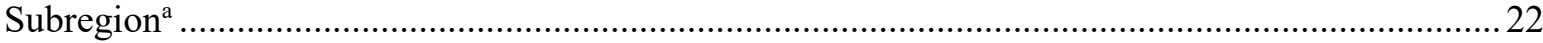

Table 4c. Theoretical and Technical East Coast Marine Energy Resources for the Southeastern

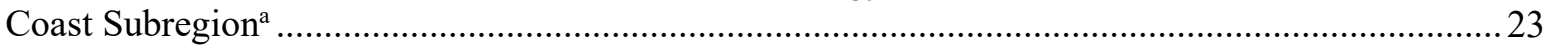

Table 4d. Theoretical and Technical East Coast Marine Energy Resources for the East Coast Region ${ }^{\mathrm{a}} . . .24$

Table 5. Theoretical and Technical Gulf of Mexico Coast Marine Energy Resources ${ }^{\mathrm{a}}$...........................225

Table 6. Theoretical and Technical Alaska Marine Energy Resources ${ }^{\mathrm{a}}$................................................26

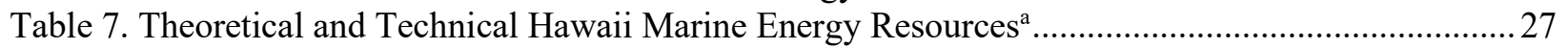

Table 8. Theoretical and Technical Puerto Rico and U.S. Virgin Islands Marine Energy Resources ${ }^{\mathrm{a}}$........ 28

Table 9. Theoretical and Technical Pacific Territories and Freely Associated States Marine Energy

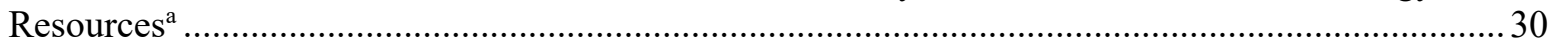

Table 10. Theoretical and Technical River Hydrokinetic Energy Resources in Inland States ${ }^{\mathrm{a}}$.................. 31 


\section{Introduction}

This report was written at the request of the U.S. Department of Energy's (DOE's) Water Power Technologies Office to provide a concise and consolidated summary of the location and quantity of utility-scale wave, tidal current, ocean current, ocean thermal, and river hydrokinetic resources. The information presented herein is intended to help improve understanding of the locations and characteristics of the resources and how they might contribute to the future energy portfolio of the United States. This work is based on several DOE-funded resource assessment studies (Haas et al. 2011; Haas 2013; Jacobson, Hagerman, and Scott 2011; Jacobson et al. 2012; Ascari et al. 2012), a review of these studies performed by the National Research Council (National Research Council (NRC) 2013), and work to update and improve resource assessment studies currently underway at the National Renewable Energy Laboratory (NREL), Pacific Northwest National Laboratory (PNNL), and Sandia National Laboratories (Sandia). Accordingly, this report presents the most up-to-date marine energy technically recoverable utility-scale resource data for the United States.

This report focuses on the technically recoverable marine energy resource that can be captured using utility-scale technologies that, when deployed in arrays, can provide megawatts to gigawatts of power and does not independently consider marine energy resources for Powering the Blue Economy applications and markets (LiVecchi et al. 2019). Many blue economy uses of marine energy have lower power requirements and can often harness low-energy marine energy resources that are not sufficiently energetic for large-scale energy generation. Accordingly, some locations where this report identifies little or no technical resource may still have sufficient resource potential to power blue economy marine energy technologies. While quantifying marine energy resources for blue economy applications is beyond the scope of this report, including them would increase the overall resource available withing the U.S. exclusive economic zone (EEZ). Further, although Powering the Blue Economy power requirements are often small, the value of energy in these markets is typically high, and there is the potential for significant market opportunities and economic benefit in harnessing marine energy for blue economy applications.

Section 2 of this document provides a high-level overview of terminology and methods used to describe and define each marine energy resource type. It also includes a short description of challenges and next steps for each resource type, based primarily on the NRC 2013 report. Sections 3 and 4 provide a description of marine energy resources at the national, state, and regional scales, respectively. Section 5 provides conclusions and a discussion of how to prioritize future research in marine energy resource assessment to support the growth of the industry. 


\section{Resource Data and Methods}

\subsection{Terminology and Units}

This report follows the resource assessment terminology used and defined by the NRC and the International Electrotechnical Commission Technical Committee 114 (International Electrotechnical Commission 2020), as shown in Figure 1. These definitions are distinct from the definitions used in the assessment of other renewable energy sectors, such as wind and solar. In particular, the definitions of 'practical' and 'technical' resource used here are closer to the 'technical' and 'gross' resource definitions, respectively, used in other renewable energy sectors (Lopez et al. 2012; Musial et al. 2016).

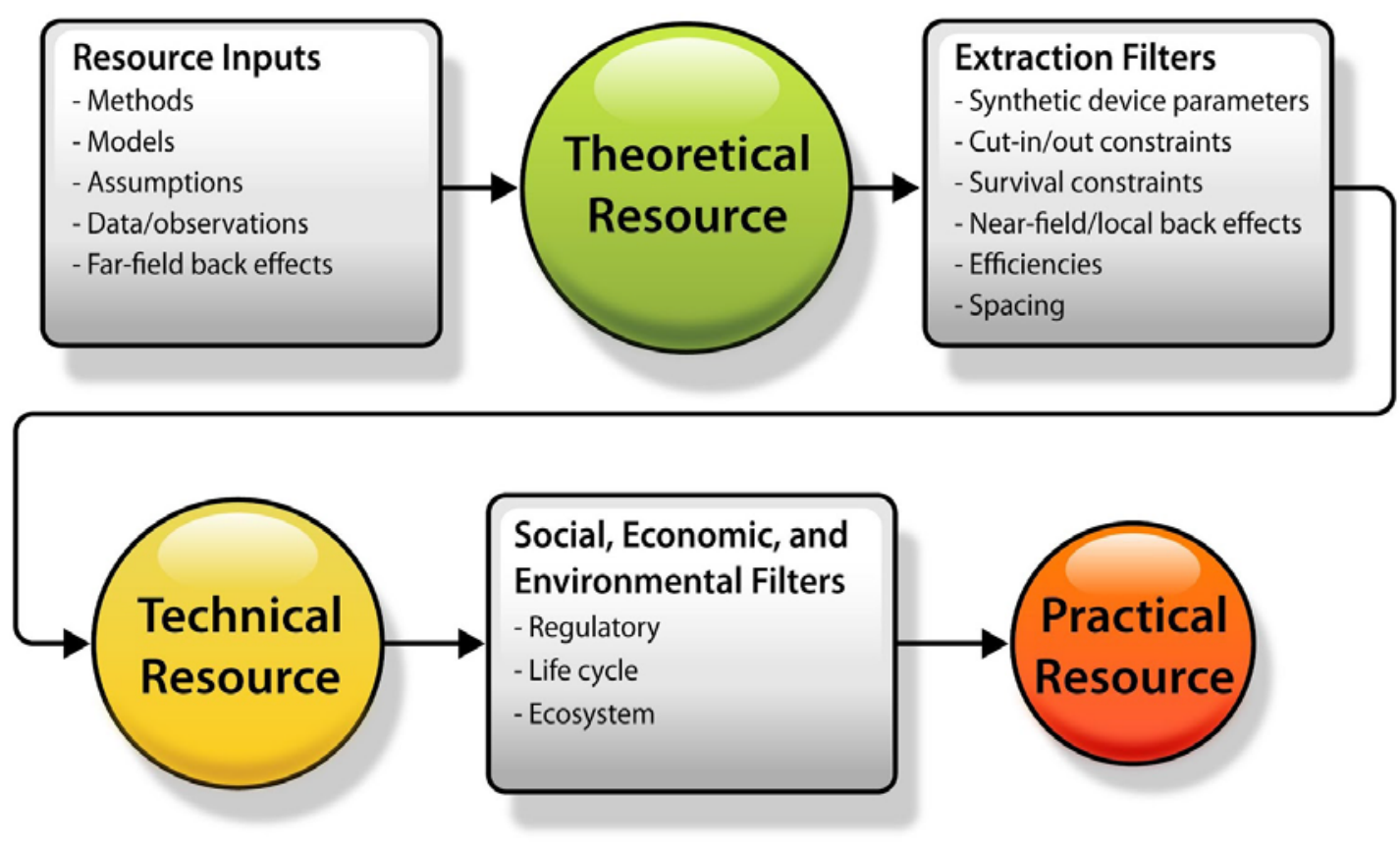

Figure 1. Classification of marine energy resource assessment.

Theoretical resource is the "energy available in the resource." Theoretical resource will always be the largest of theoretical, technical, and practical resource estimates. Estimation of the theoretical resource depends on the accuracy, as well as the temporal and spatial resolution, of the model used.

Technical resource is the "proportion of the theoretical resource that can be captured using existing technology options without consideration of external constraints." Technical resource will always be smaller than theoretical resource estimates and larger than practical resource estimates. Estimation of the technical resource is a function of the type of technology being modeled and the model's ability to sufficiently quantify the effect of the technology on the theoretical resource. 
Practical resource is the "proportion of the technical resource that is available after consideration of external constraints." External constraints include, but are not limited to, economic, environmental, and regulatory considerations. Practical resource will always be the smallest of theoretical, technical, and practical resource estimates.

The practical resource for marine energy technologies depends heavily on regulatory constraints, social acceptance, competing uses, and other factors that are highly uncertain and difficult to accurately quantify. As such, consideration of the practical resource is beyond the scope of this report - only estimates of the theoretical and technical resources are presented, with a focus on the technical resource. Throughout this work, wherever the term 'resource' is used without a 'practical' or 'theoretical' qualifier, it refers to the technical resource.

In this report, the marine energy resource is reported in terms of four metrics:

- Terawatt hours per year (TWh/yr) is the amount of energy the marine energy resource could generate per year. This metric is valuable because it indicates the average amount of energy the resource can provide per year. $1 \mathrm{e} 12 \mathrm{watts}=1$ trillion watts $=1$ terawatt.

- Number of average homes the marine energy resource could power per year. This metric is a more readily conceptualized indication of how much electricity the resource could produce. In 2019, the average U.S. residential electricity customer consumed 10,649 kilowatt hours (kWh) of energy per year (U.S. Energy Information Administration 2020). One TWh/yr can provide electricity for approximately 94,000 U.S. homes given 2019 consumption rates.

- Percentage of the region's electricity generation the marine energy resource could provide. This metric allows regions to consider the marine energy resource relative to present-day electricity generation (as of 2019). This allows state and regional planners to better consider opportunities to develop marine energy resources, including opportunities for energy export.

- Percentage of electricity generation by all 50 states that the marine energy resource could provide. This metric allows regional resources to be compared to the nation's total generation. This provides a common reference $(4,127 \mathrm{TWh} / \mathrm{yr}$ in 2019), rather than the metric in the previous bullet, which varies by region (U.S. Energy Information Administration 2020).

\subsubsection{Capacity Estimates}

In addition to the metrics defined above, it can also be useful to discuss the amount of electrical generation capacity (i.e., the nameplate capacity of devices installed in megawatts (MW)) that would need to be installed to capture the resource, because this is another metric that is more familiar to utility operators, policymakers, and the general public. Where we do estimate capacity in this work (i.e., in Section 5), we do so according to the following equation: 


$$
\text { Capacity }[\mathrm{GW}]=\frac{\text { Energy Capture }\left[\frac{\mathrm{TWh}}{\mathrm{yr}}\right]}{\text { Capacity Factor }} * \frac{1000[\mathrm{GW} / \mathrm{TW}]}{8760[\mathrm{~h} / \mathrm{yr}]}
$$

We use the capacity factor estimates from (Jenne, Yu, and Neary 2015), shown in Table 1 . This approach certainly neglects many details of device performance and resource variability. However, a simple analysis of existing marine energy technologies in realistic U.S. resource conditions indicates that these values are at least technically achievable. Therefore, for a technology that is precommercial, we believe this approach is at least reasonable for estimating the potential scale of future projects in terms of the resource available. However, the reader should not interpret any statements of capacity as anything more than a first-order estimate of marine energy opportunities in terms of installed capacity and a starting point for more detailed investigation.

Table 1. Capacity Factors for Each Resource Type

\begin{tabular}{|l|c|}
\hline \multicolumn{1}{|c|}{$\begin{array}{c}\text { Resource } \\
\text { Type }\end{array}$} & $\begin{array}{c}\text { Capacity } \\
\text { Factor }\end{array}$ \\
\hline Wave & $30 \%$ \\
\hline Tidal & $30 \%$ \\
\hline Ocean-Current & $70 \%$ \\
\hline $\begin{array}{l}\text { Ocean thermal energy } \\
\text { conversion (OTEC) }\end{array}$ & $100 \%{ }^{4}$ \\
\hline River & $30 \%$ \\
\hline
\end{tabular}

\subsection{Ocean Wave Energy}

There have been several notable wave resource assessments over the last two decades that have gradually improved the accuracy and spatial coverage of our understanding of the U.S. wave energy opportunity (Jacobson, Hagerman, and Scott 2011; García-Medina, Özkan-Haller, and Ruggiero 2014; Bedard and Hagerman 2004). In this report, the theoretical resource results and data are from a forthcoming manuscript authored by researchers at NREL and PNNL (Kilcher, Garcia-Medina, and Yang 2021). This data set is distinct from the new high-resolution wave hindcasts because the methodology required a more detailed breakdown of the wave field (i.e., directional spectra and wave energy source terms) than is contained in the new high-resolution wave data set generated by PNNL and Sandia (Yang and Neary 2020; Wu et al. 2020; Allahdadi et al. 2019). The forthcoming manuscript builds on the previous DOE-funded resource assessment and resolves several limitations of that work that were identified in an NRC review (Jacobson, Hagerman, and Scott 2011; National Research Council 2013). The forthcoming manuscript improves upon the 2011 methodology in three important ways:

1. It extends the resource area to cover the entire U.S. EEZ

\footnotetext{
${ }^{4}$ An OTEC capacity factor was not estimated in Jenne, Yu, and Neary (2015), but the technology is expected to be very consistent, so we utilize a value of $100 \%$.
} 
2. It expands the definition of wave resource to include waves generated by local winds within the EEZ

3. It accounts for wave directionality using a vector line-integral to compute the total wave energy that arrives at the edge of the EEZ.

The wave energy technical resource is calculated from this same data set using the methodology described in Chapter 4.N of DOE's 2015 Quadrennial Technology Review (QTR) (U.S. Department of Energy 2015). The basis for this methodology is summarized by:

If an array consists of an arbitrarily large number of rows, it is theoretically possible to extract almost all incoming wave energy. In practice, however, there will be a point of diminishing returns, where installing additional rows of devices will provide only marginal increases in absorbed energy. Accordingly, there will be a point where deploying additional rows of [wave energy converters] is not economically beneficial. To evaluate the technical wave resource, it is assumed that once the resource has been depleted to $8 \mathrm{~kW} / \mathrm{m}$ as it passes through an array, it is not economical to deploy additional rows. In addition, the analysis assumed that the array has an overall mechanical to electrical conversion efficiency of $90 \%$.

The equation that defines this method of estimating the technical resource is:

$$
\frac{\text { wave array output }}{\text { meter }}=\left(\frac{\text { inflow energy }}{\text { meter }}-\frac{\text { outflow energy }}{\text { meter }}\right) * \text { conversion efficiency }
$$

While our work uses the same outflow energy value as in the QTR $(8 \mathrm{~kW} / \mathrm{m})$, we make two different assumptions that effect the magnitude of the wave energy technical resource. First, we account for wave directionality by using a "bidirectional dot-product" to quantify energy that is propagating both onshore and offshore. In contrast, the QTR did not account for directionality. Second, we change the conversion efficiency from $90 \%$ to $70 \%$. We made this adjustment because we currently have no operational knowledge of wave array efficiencies, which we believe require a more conservative approach.

We apply this equation to the data sets developed for estimating the theoretical resource at both 10 nautical miles (nmi) from shore (the "inner shelf resource") and at $200 \mathrm{nmi}$ from shore (the resource at the EEZ boundary) to compute the technical resource. These two values provide upper and lower bounds (respectively) on estimates of the United States' technical wave resource, depending on how far from shore it is technically and economically viable to generate wave energy.

The theoretical and technical resources for states along the U.S. West Coast were calculated by breaking the EEZ (i.e., out to $200 \mathrm{nmi}$ from shore) into three sections, separated by extending the borders between the states offshore directly westward (i.e., along lines of constant latitude). On the East Coast, the southeast subregion was separated from the mid-Atlantic subregion by extending the border between North Carolina and Virginia directly eastward. The border between New England and the mid-Atlantic subregions was separated by a line that extends the 
state-water boundary between New York and Rhode Island to the southeast (i.e., the line connecting $41.419 \mathrm{~N}, 72.021 \mathrm{~W}$ to $36.667 \mathrm{~N}, 67.670 \mathrm{~W}$ separates the two subregions).

\subsubsection{Ocean Wave Energy: Challenges and Future Work}

The new high-resolution wave hindcast data sets are being made publicly available via cloudhosting services (Yang and Neary 2020). That data will also be accessible via the MHK Atlas by the end of 2021. The improved resolution of this data set is expected to help project developers identify specific sites that are suitable for specific wave technologies.

More work is needed to delineate the wave resource, which is currently quantified in terms of the entire EEZ by state along the Atlantic and Gulf coasts. This is especially challenging because state boundaries are typically only defined out to $3 \mathrm{nmi}$ from shore ( $9 \mathrm{nmi}$ in the Gulf), which makes other definitions arbitrary. It was relatively simple to accomplish this on the West Coast, where state coastlines are long and straight, but it is significantly more challenging to do so for East Coast states. Additionally, more work is needed to build consensus around a methodology for estimating the technical resource because divergent approaches exist (Jacobson, Hagerman, and Scott 2011; U.S. Department of Energy 2015).

\subsection{Tidal Current Energy}

The tidal data reported here comes primarily from the 2011 DOE-funded wave resource assessment (Haas et al. 2011). That work modeled the tides along the entire U.S. coastline, then calculated the power potential at each channel where the tidal flows exceeded $0.5 \mathrm{~m} / \mathrm{s}$ over an area greater than $0.5 \mathrm{~km}^{2}$ and with a depth greater than $5 \mathrm{~m}$. The power available at these 'hot spots' was estimated in terms of a theoretical limit based on tidal hydraulics (Garrett and Cummins 2005). This approach provides the maximum power that can be extracted from a function of drag added to it. Below this 'maximum power' point, more energy can be extracted by adding more turbines. However, above this 'maximum power' point, adding more turbines will actually constrict the flow to the point that the array as a whole extracts less energy (i.e., it restricts and slows the flow).

The 2011 assessment included a fairly detailed model validation effort based on publicly existing data at the time, but an exhaustive model validation effort for each hot spot is a big challenge. As time has passed, the energy at several locations has been identified to have been underestimated, which has motivated refined modeling efforts (Gunawan, Neary, and Colby 2014). This work utilizes new model data for four locations: Long Island Sound coupled to the New York/New Jersey bight via the East River, a refined model of Portsmouth Harbor (Lower Piscataqua River) on the New Hampshire/Maine border, Cape Cod Canal that connects Buzzards Bay to Cape Cod Bay, and a new model of Delaware Bay (Kilcher, Haas, and Muscalus 2021). All other data presented are from the original 2011 report. In the QTR, the tidal energy technical resource was estimated to be $50 \%-75 \%$ of the theoretical resource. For simplicity and to be conservative, we take the technical resource to be $50 \%$ of the theoretical resource estimates provided in Haas et al. (2011).

\subsubsection{Tidal Current Energy: Challenges and Future Work}

A definitive estimate of the technical potential of tidal energy requires a detailed understanding of the energy dissipated to turbulence in the wake of tidal energy devices. This is because the 
wake turbulence also contributes to the effective drag in the channel and, thereby, reduces the total amount of energy that can be extracted. Furthermore, the support structures of the turbines also contribute directly to increased channel drag as well as generate wake turbulence. Finally, it seems likely that most tidal arrays will be restricted to operate at a depth where there is zero probability that they pose a risk to vessel traffic. As such, the energy in the surface layer may be more technically challenging to harness.

A more detailed understanding of energy dissipation in turbine wakes, and the associated increase in drag, is required to improve our understanding of the tidal energy technical resource. With an improved understanding of these 'wake losses,' it will be possible to model arrays of turbines to identify optimal energy extraction scenarios. By iterating this process across all of the nation's tidal energy hot spots, it will be possible to obtain a more rigorous estimate of the technical resource potential. This type of iterative approach, where realistic models of turbines are simulated to extract energy and increase drag in tidal circulation models, is also needed to identify whether complex channel geometries (e.g., those in Puget Sound) might be capable of yielding more energy than simple hydraulic models currently indicate (Wang and Yang 2017).

Furthermore, the assumptions in the underlying theory for tidal energy resource assessment are not always relevant to the sites where it was applied (Garrett and Cummins 2005). Many tidally forced regions are far more complicated than 'a single channel connecting two basins.' Instead, these regions are often an interconnected web of channels connecting many basins (e.g., Puget Sound and the San Juan Islands in Washington state). In these geometries, the interactions and phase-lags between channels complicate the application of, and violate several assumptions of, the theoretical approach of Garrett and Cummins. High-resolution models with accurate bathymetry and the ability to simulate turbines in the tidal flow are being used to address these challenges.

The data used here still rely primarily on the filters identified in the original assessment $(>0.5$ $\mathrm{m} / \mathrm{s},>0.5 \mathrm{~km}^{2},>5-\mathrm{m}$ depth). However, as new tidal energy technologies emerge - for example, designed to meet the objectives of DOE's Powering the Blue Economy initiative - to harness energy at lower flow speeds, or at smaller sites, the tidal energy resource could grow considerably. For example, the existing surface area filter alone omits $66 \%$ of sites that were otherwise identified to have strong tidal currents. If this happens, a more detailed assessment of the 'low speed' or 'small site' tidal resource may be worthwhile. Furthermore, new tidal energy technologies that minimize wake losses would also increase the technical resource.

More work is needed to collect measurements that can be used to validate models at potentially promising tidal energy sites - and also to improve the resolution of existing models. The national laboratories have already started this work: New measurements and new models have been made

for the Western Passage of Maine and several sites in Puget Sound; measurements are planned in Cook Inlet, Alaska. As these data sets improve our understanding of the tidal energy resource, the data will be made available via the MHK Atlas and will be used to improve national resource estimate totals.

\subsection{Ocean Current Energy}

The ocean current data used here comes exclusively from the 2013 DOE-funded resource assessment of ocean current energy (Haas 2013). While that work assessed the ocean current 
resource across the majority of the U.S. coastline, the report focused primarily on the Gulf Stream, because this contains the vast majority of the United States' ocean current resource. Other wind-driven currents (i.e., nontidal currents) in U.S. waters are relatively small (i.e., velocities of $\sim 0.2 \mathrm{~m} / \mathrm{s}$ or less).

The 2013 report used a simplified ocean circulation model to assess the theoretical potential of the Gulf Stream. This was based on similar principles as the tidal assessment, where power was maximized as a function of drag applied to the current (Gulf Stream). As the drag (number of turbines) increased, a maximum power was identified beyond which the currents slowed such that the total power was reduced. The technical resource was estimated for the Gulf Stream (from Florida to North Carolina within the U.S. EEZ; i.e., including the Florida Current), by assuming a device efficiency of $30 \%$.

\subsubsection{Ocean Current Energy: Challenges and Future Work}

There already exists a wide range in the theoretical resource estimates for the Gulf Stream (from $1 \mathrm{GW}$ to $>200 \mathrm{GW}$ ). This wide range is related to the challenges of accurately modeling the dynamics of the Gulf Stream under the influence of large-scale energy extraction. At some point, experts agree that the Gulf Stream would likely shift its course around arrays of turbines that extracted large amounts of energy, though the levels of energy extraction necessary to cause any of these shifts are unknown.

The details of predicting this 'inflection point' are complex. Understanding where, when, and under what conditions the current will divert around an array is critical to estimating a project's economic viability. This problem spans nearly all oceanic spatial scales: the north Atlantic Ocean itself (i.e., the wind-driven gyre circulation) to the turbulence and stratification along the southeastern United States that controls the drag in the Gulf Stream. Furthermore, though the Gulf Stream is known to play an important role in the global heat budget, the climatic and geologic implications of extracting energy from the Gulf Stream are not yet clearly understood (Minobe et al. 2008; Palter 2015; Nunn et al. 2007).

Several recent works have begun to investigate and explore the processes and challenges to energy extraction in the Gulf Stream. This includes modeling studies that account for energy extraction by arrays of turbines in the Florida Current (Haas et al. 2017) as well as detailed modeling and measurement efforts offshore of North Carolina (Lowcher et al. 2017; Muglia, Seim, and Taylor 2020; Bane et al. 2017). We believe the next step would be to take a more coordinated and comprehensive approach to answering these questions. That is, though the challenge of doing so is great, it would be wise to take a more detailed look at the Gulf Stream system before pursuing large- or even medium-scale energy extraction opportunities.

Fortunately, thanks largely to the growing trove of high-quality measurements of the Gulf Stream, the improvement in unstructured grid circulation models, and the expanding power of computational resources, there is a real opportunity to improve our understanding of oceancurrent energy extraction.

\subsection{Ocean Thermal Energy Conversion (OTEC)}

The ocean thermal data used here comes exclusively from the 2012 DOE-funded resource assessment of ocean thermal energy (Ascari et al. 2012). That work provides a global assessment of OTEC (electricity generation) via a detailed analysis based on a specific OTEC technology 
and a two-year HYbrid Coordinate Ocean Model (HYCOM) simulation of ocean temperature and currents. This work takes the technical resource estimates directly from Ascari et al. (2012).

The Ascari report also discussed the opportunity to use seawater for cooling and provided a map that shows locations where $8^{\circ} \mathrm{C}$ water is less than 300 meters from the surface, but the potential electricity savings that can be attributed to this resource was not quantified. This opportunity may be worth more investigation in locations such as the U.S. West Coast and Hawaii, where summer cooling loads are sizable and cold water is available near the surface.

\subsubsection{Ocean Thermal Energy: Challenges and Future Work}

As pointed out by the NRC 2013 review, the OTEC resource assessment could be significantly improved by a longer-duration simulation (at least a decade) and by accounting for seasonality of the resource. Future assessments should also explore the opportunity in terms of a broader mix of available technology options (rather than just one). Furthermore, a more detailed investigation of the influence of OTEC water discharge on circulation patterns in the vicinity of the plant is needed to quantify the resource magnitude and to understand other impacts of OTEC on the ocean (e.g., ocean chemistry and biological changes caused by bringing deep-potentially nutrient-rich — waters to the surface).

\subsection{River Current Energy}

The river data reported here comes exclusively from the 2012 DOE-funded river resource assessment (Jacobson et al. 2012). This data is a collection of more than 71,000 river segments throughout the United States and is available on the MHK Atlas. The theoretically available power for each segment was calculated according to the standard hydrologic engineering equation based on the river volume flow, $Q$, and the head, $H$ :

$$
P=\gamma \cdot Q \cdot H
$$

Where $\gamma$ is the specific weight of water. Volume flux $(Q)$ and elevation drop $(H)$ of each river segment were used to calculate the theoretically available power. The data for this analysis, for the contiguous United States (CONUS), was calculated from the NHDPlus GIS database containing discharge rates and channel slope information for discrete river segments. The data for Alaska was calculated using a combination of resources, including the Idaho National Laboratory's Virtual Hydropower Prospector, Google Earth, and U.S. Geological Survey stream gages. Segments with flow rates less than 1,000 cubic feet per second were omitted from the analysis, as were stream segments with existing hydroelectric plants or nonpowered dams.

The technical resource was calculated based on a recovery factor for each segment that depended on water velocity and depth during low flow conditions, maximum device packing density, device efficiency, flow statistics, channel slope, and feedback effects between turbine presence and hydraulic head. There were $31 \%$ of segments that had a non-zero recovery factor 0 . This work takes the technical resource estimates directly from Jacobson et al. (2012).

NREL took the data from this resource assessment, which was not previously organized by state, and grouped it by state. This was done using a simple geographic analysis to identify the state in which each segment was contained. Where a segment was on or near a border between states, the power in that segment was divided equally between those states. We utilized the Natural Earth 
database, "first order admin" data layer for state boundaries. ${ }^{5}$ Because state borders are known to follow rivers - but, often, there was not a perfect match between the river segment data and the borders data - we utilized a 5-km buffer to identify overlap between rivers and borders; that is, any river segment that was within $5 \mathrm{~km}$ of the border was identified to be on the border and, therefore, the power in that segment was shared between those states.

It is also important to note that the riverine resource quantified here overlaps with the theoretical potential of conventional hydropower. In other words, this energy could be extracted via conventional hydropower (dams) or marine energy turbines that do not require dams or other flow confinement structures - but not with both technologies simultaneously.

\subsubsection{River Current Energy: Challenges and Future Work}

The assessment of river hydrokinetic resources in terms of the standard hydrologic power equation was an important first step and was probably the only defensible methodology that could be applied nationwide with data that was available at the time. However, the method of quantifying the technical resource is not consistent with the methodology proposed for quantifying river resource by the International Electrotechnical Commission (IEC) resource assessment technical specification (International Electrotechnical Commission 2019). In particular, while the theoretically extractable energy is certainly limited by the hydrologic equation (Section 2.6), and the technical resource methodology was a good first attempt based on the data available, the uncertainty in the technical resource assessment is large.

The IEC technical specification provides a methodology that yields much more accuracy, but it is based on detailed knowledge of the river bathymetry and requires significant computational resources. However, applying this methodology nationally is a very big challenge because the bathymetry needed does not exist uniformly at the resolution necessary. Therefore, it seems more reasonable that project developers use local knowledge and/or the existing resource assessment data (on the MHK Atlas) to identify potential sites of interest and proceed with site-specific assessments. As we gain a clearer understanding of the important considerations for these projects through the iterative experience of siting and installing them (e.g., sedimentation and river meandering, turbine wakes, competing uses of rivers, etc.), an improved methodology for estimating the technical resource may become apparent. Until then, it seems prudent to simply acknowledge the large uncertainty in the nation's river resource and focus instead on conducting rigorous and thorough site assessments and developing technologies that can operate at those sites.

\section{U.S. Marine Energy Resources}

The total technical marine energy resource for the CONUS, extending to the EEZ, is calculated to be $830 \mathrm{TWh} / \mathrm{yr}$, equivalent to the power needs of $78-$ million homes ${ }^{6}$ - or $20 \%$ of the total electricity generation by U.S. states in $2019^{7}$ (Table 2a). The two largest marine energy resources for the CONUS are ocean thermal and wave resources, with 400 and $290 \mathrm{TWh} / \mathrm{yr}$, respectively.

\footnotetext{
${ }^{5}$ www.naturalearthdata.com

${ }^{6}$ In 2019, the average annual electricity consumption for a U.S. residential utility customer was $10,649 \mathrm{kWh}$, an average of about $877 \mathrm{kWh}$ per month: https://www.eia.gov/tools/faqs/faq.php?id=97\&t=3

${ }^{7}$ Net Generation by state by type of producer by energy source: https://www.eia.gov/electricity/data/state/
} 
The river current resource in the CONUS is $79 \mathrm{TWh} / \mathrm{yr}$, the ocean current resource is $49 \mathrm{TWh} / \mathrm{yr}$, and the tidal current resource is $15 \mathrm{TWh} / \mathrm{yr}$ (all with the various uncertainties noted in the section above). The top five tidal sites in the CONUS include one location each in Washington, Delaware/New Jersey, Maine, New York, and California.

When Alaska and Hawaii are included, the total technical marine energy resource increases to $2,300 \mathrm{TWh} / \mathrm{yr}$, equivalent to the power needs of 220 -million homes, or $57 \%$ of the total electricity generation by U.S. states in 2019 (Table 2b). This increase is largely attributable to the substantial wave and tidal resources in Alaska.

Finally, when the U.S territories and freely associated states in the Pacific and Caribbean are included, the total technical marine energy resource is $6,400 \mathrm{TWh} / \mathrm{yr}$ - equivalent to the power needs of 600 -million homes, or $160 \%$ of the total electricity generation by U.S. states in 2019 (Table 2c).

Because resource assessments for the five marine energy resource types (wave, tidal currents, ocean currents, OTEC, and river currents) have not been completed for all U.S. states, territories, and freely associated states, the technical resources here underestimate the full marine energy resources contained within all U.S. land and EEZ extents. 
Table 2a. Theoretical and Technical Marine Energy Resources for the CONUS ${ }^{a}$

\begin{tabular}{|c|c|c|c|c|}
\hline & $\begin{array}{r}\text { Theoretical } \\
\text { Resource } \\
(T W h / y r)\end{array}$ & $\begin{array}{r}\text { Technical } \\
\text { Resource }^{b} \\
(\mathrm{TWh} / \mathrm{yr})\end{array}$ & $\begin{array}{r}\text { Technical } \\
\text { Resource as } \\
\text { Potential Number } \\
\text { of Homes } \\
\text { Powered }\end{array}$ & $\begin{array}{r}\text { Technical } \\
\text { Resource as } \\
\text { Percent of US } \\
\text { Electricity } \\
\text { Generation } \\
\text { (4126.7 TWh) } \\
(\%)\end{array}$ \\
\hline \multicolumn{5}{|l|}{\begin{tabular}{|l|} 
CONUS \\
Marine Energy Resources
\end{tabular}} \\
\hline Wave (EEZ) & 860 & 290 & $27,000,000$ & 7.1 \\
\hline Wave (to $10 \mathrm{nmi}$ ) & 540 & 190 & $18,000,000$ & 4.7 \\
\hline Tidal & 29 & 15 & $1,400,000$ & 0.35 \\
\hline \multicolumn{5}{|l|}{$\begin{array}{r}\text { Top 5 Tidal Sites Ranked by } \\
\text { Power } \\
\end{array}$} \\
\hline Admiralty Inlet Entrance, WA & 4.0 & 2.0 & 190,000 & 0.05 \\
\hline Delaware Bay, DE/NJ & 2.8 & 1.4 & 130,000 & 0.03 \\
\hline $\mathrm{E}$ of Cross Island, ME & 2.4 & 1.2 & 110,000 & 0.03 \\
\hline $\begin{array}{r}\text { Fishers Island Sound Central } \\
\text { Entrance, NY }\end{array}$ & 2.1 & 1.1 & 100,000 & 0.03 \\
\hline San Francisco Bay Entrance, CA & 1.6 & 0.78 & 73,000 & 0.02 \\
\hline Ocean Current & 160 & 49 & $4,600,000$ & 1.2 \\
\hline Ocean Thermal & not reported & 400 & $37,000,000$ & 9.6 \\
\hline River & 1,100 & 79 & $7,400,000$ & 1.9 \\
\hline $\begin{array}{l}\text { Total (Wave to EEZ + Tidal + } \\
\text { Ocean Current + Ocean } \\
\text { Thermal + River) }\end{array}$ & 2,100 & 830 & $78,000,000$ & 20 \\
\hline $\begin{array}{l}\text { Total (Wave to } 10 \mathrm{nmi}+\text { Tidal + } \\
\text { Ocean Current + Ocean } \\
\text { Thermal + River) }\end{array}$ & 1,800 & 730 & $69,000,000$ & 18 \\
\hline
\end{tabular}

${ }^{a}$ All values are listed to two significant figures; therefore, totals shown may not equal the sum of values.

${ }^{b}$ Detailed methodologies for estimating Technical Resource are provided in Section 2. 
Table 2b. Theoretical and Technical Marine Energy Resources for All U.S. States ${ }^{a}$

\begin{tabular}{|c|c|c|c|c|}
\hline & $\begin{array}{r}\text { Theoretical } \\
\text { Resource } \\
(T W h / y r)\end{array}$ & $\begin{array}{r}\text { Technical } \\
\text { Resource }^{b} \\
\text { (TWh/yr) }\end{array}$ & $\begin{array}{r}\text { Technical } \\
\text { Resource as } \\
\text { Potential Number } \\
\text { of Homes } \\
\text { Powered }\end{array}$ & $\begin{array}{r}\text { Technical } \\
\text { Resource as } \\
\text { Percent of US } \\
\text { Electricity } \\
\text { Generation } \\
\text { (4126.7 TWh) } \\
(\%)\end{array}$ \\
\hline \multicolumn{5}{|l|}{$\begin{array}{l}\text { US States } \\
\text { Marine Energy Resources }\end{array}$} \\
\hline Wave (EEZ) & 3,300 & 1,400 & $130,000,000$ & 34 \\
\hline Wave (to $10 \mathrm{nmi}$ ) & 1,800 & 770 & $72,000,000$ & 19 \\
\hline Tidal & 440 & 220 & $21,000,000$ & 5.4 \\
\hline \multicolumn{5}{|l|}{$\begin{array}{r}\text { Top 5 Tidal Sites Ranked by } \\
\text { Power } \\
\end{array}$} \\
\hline Cook Inlet, AK & 160 & 80 & $7,500,000$ & 1.9 \\
\hline Chatham Strait, AK & 110 & 53 & $5,000,000$ & 1.3 \\
\hline Clarence Strait, AK & 36 & 18 & $1,700,000$ & 0.44 \\
\hline Summer Strait, AK & 23 & 12 & $1,100,000$ & 0.28 \\
\hline $\mathrm{N}$ of Inian Islands, $\mathrm{AK}$ & 22 & 11 & $1,100,000$ & 0.27 \\
\hline Ocean Current & 160 & 49 & $4,600,000$ & 1.2 \\
\hline Ocean Thermal & not reported & 540 & $51,000,000$ & 13 \\
\hline River & 1,300 & 99 & $9,300,000$ & 2.4 \\
\hline $\begin{array}{l}\text { Total (Wave to EEZ + Tidal + } \\
\text { Ocean Current + Ocean } \\
\text { Thermal + River) }\end{array}$ & 5,200 & 2,300 & $220,000,000$ & 57 \\
\hline $\begin{array}{l}\text { Total (Wave to } 10 \mathrm{nmi}+\text { Tidal + } \\
\text { Ocean Current + Ocean } \\
\text { Thermal + River) }\end{array}$ & 3,800 & 1,700 & $160,000,000$ & 41 \\
\hline
\end{tabular}

${ }^{a} A l l$ values are listed to two significant figures; therefore, totals shown may not equal the sum of values.

${ }^{b}$ Detailed methodologies for estimating Technical Resource are provided in Section 2. 
Table 2c. Theoretical and Technical Marine Energy Resources for All U.S. States, Territories, and Freely Associated States ${ }^{a}$

\begin{tabular}{|c|c|c|c|c|}
\hline & $\begin{array}{r}\text { Theoretical } \\
\text { Resource } \\
(\mathrm{TWh} / \mathrm{yr})\end{array}$ & $\begin{array}{r}\text { Technical } \\
\text { Resource }^{b} \\
(\mathrm{TWh} / \mathrm{yr})\end{array}$ & $\begin{array}{r}\text { Technical } \\
\text { Resource as } \\
\text { Potential Number } \\
\text { of Homes } \\
\text { Powered }\end{array}$ & $\begin{array}{r}\text { Technical } \\
\text { Resource as } \\
\text { Percent of US } \\
\text { Electricity } \\
\text { Generation } \\
\text { (4126.7 TWh) } \\
(\%)\end{array}$ \\
\hline \multicolumn{5}{|l|}{$\begin{array}{l}\text { US States, Territories, and } \\
\text { Freely Associated States } \\
\text { Marine Energy Resources }\end{array}$} \\
\hline Wave (EEZ) & 3,300 & 1,400 & $130,000,000$ & 34 \\
\hline Wave (to $10 \mathrm{nmi}$ ) & 1,900 & 770 & $72,000,000$ & 19 \\
\hline Tidal & 440 & 220 & $21,000,000$ & 5.4 \\
\hline \multicolumn{5}{|l|}{$\begin{array}{r}\text { Top } 5 \text { Tidal Sites Ranked by } \\
\text { Power }\end{array}$} \\
\hline Cook Inlet, AK & 160 & 80 & $7,500,000$ & 1.9 \\
\hline Chatham Strait, AK & 110 & 53 & $5,000,000$ & 1.3 \\
\hline Clarence Strait, AK & 36 & 18 & $1,700,000$ & 0.44 \\
\hline Summer Strait, AK & 23 & 12 & $1,100,000$ & 0.28 \\
\hline $\mathrm{N}$ of Inian Islands, $\mathrm{AK}$ & 22 & 11 & $1,100,000$ & 0.27 \\
\hline Ocean Current & 160 & 49 & $4,600,000$ & 1.2 \\
\hline Ocean Thermal & not reported & 4,600 & $440,000,000$ & 110 \\
\hline River & 1,300 & 99 & $9,300,000$ & 2.4 \\
\hline $\begin{array}{l}\text { Total (Wave to EEZ + Tidal + } \\
\text { Ocean Current + Ocean } \\
\text { Thermal + River) }\end{array}$ & 5,200 & 6,400 & $600,000,000$ & 160 \\
\hline $\begin{array}{l}\text { Total (Wave to } 10 \mathrm{nmi}+\text { Tidal + } \\
\text { Ocean Current + Ocean } \\
\text { Thermal + River) }\end{array}$ & 3,800 & 5,800 & $540,000,000$ & 140 \\
\hline
\end{tabular}

${ }^{a} A l l$ values are listed to two significant figures; therefore, totals shown may not equal the sum of values.

${ }^{b}$ Detailed methodologies for estimating Technical Resource are provided in Section 2. 


\section{Marine Energy Resources by State/Region}

Marine energy theoretical and technical resources are reported by region in Table 3-Table 10.

\subsection{West Coast}

West Coast marine energy resources are reported by state and by regional totals (Tables 3a-3d).

In California, the marine energy technical resource total extending to the EEZ is $140 \mathrm{TWh} / \mathrm{yr}$, equivalent to the power needs of 13 -million homes, $69 \%$ of California's 2019 net electricity generation, or $3.4 \%$ of the total electricity generation by U.S. states in 2019 (Table 3a). The wave resource accounts for nearly all of the state's marine energy resource (140 TWh/yr total). The tidal resource in the San Francisco Bay entrance has the potential to power an additional 73,000 homes and is the fifth-largest tidal resource in the CONUS.

In Oregon, the marine energy technical resource total extending to the EEZ is $95 \mathrm{TWh} / \mathrm{yr}$, equivalent to the power needs of 8.9-million homes, which is 1.5 times Oregon's 2019 net electricity generation, or $2.3 \%$ of the total electricity generation by U.S. states in 2019 (Table $3 \mathrm{~b})$. The wave resource accounts for $93 \mathrm{TWh} / \mathrm{yr}$ of the $95 \mathrm{TWh} / \mathrm{yr}$ total and could allow Oregon to be a net exporter of wave-powered electricity.

In Washington, the marine energy technical resource total that extends to the EEZ is $12 \mathrm{TWh} / \mathrm{yr}$, which is small due to the method used to calculate the wave resource, because wave energy that propagates southward from the Canadian EEZ does not count toward the U.S. total. However, if we assume that Canada does not extract this energy before it propagates into U.S. waters, then there is significantly more wave energy available in Washington. For example, if the wave resource to $10 \mathrm{nmi}$ is used instead of the wave resource to the EEZ limit, Washington's marine energy technical resource total is $43 \mathrm{TWh} / \mathrm{yr}$, equivalent to the power needs of 4-million homes, $40 \%$ of Washington's 2019 net electricity generation, or $1.0 \%$ of the total electricity generation by U.S. states in 2019 (Table 3c). Admiralty Inlet is a particularly energetic site.

Overall, the West Coast Region's marine energy technical resource total extending to the EEZ is $250 \mathrm{TWh} / \mathrm{yr}$, equivalent to the power needs of 23 -million homes, 67\% of the West Coast's 2019 net electricity generation, or $6.0 \%$ of the total electricity generation by U.S. states in 2019 (Table $3 \mathrm{~d})$. The wave resource accounts for $240 \mathrm{TWh} / \mathrm{yr}$ of the $250 \mathrm{TWh} / \mathrm{yr}$ total. The tidal sites and river hydrokinetics of the West Coast have the potential to power 1-million homes. There are no ocean current or OTEC resources along the West Coast. 
Table 3a. Theoretical and Technical West Coast Marine Energy Resources for California ${ }^{a}$

\begin{tabular}{|c|c|c|c|c|c|}
\hline & $\begin{array}{r}\text { Theoretical } \\
\text { Resource } \\
(\mathrm{TWh} / \mathrm{yr})\end{array}$ & $\begin{array}{r}\text { Technical } \\
\text { Resource }^{\mathrm{b}} \\
\text { (TWh/yr) }\end{array}$ & $\begin{array}{r}\text { Technical } \\
\text { Resource as } \\
\text { Potential } \\
\text { Number of } \\
\text { Homes } \\
\text { Powered }\end{array}$ & \begin{tabular}{|r|} 
Technical \\
Resource as \\
Percent of 2019 \\
Regional \\
Electricity \\
Generation in \\
CA \\
$(201.8$ TWh) \\
$(\%)$
\end{tabular} & $\begin{array}{r}\text { Technical } \\
\text { Resource as } \\
\text { Percent of US } \\
\text { Electricity } \\
\text { Generation } \\
(4126.7 \text { TWh) } \\
(\%)\end{array}$ \\
\hline \multicolumn{6}{|l|}{\begin{tabular}{|l|} 
California \\
Marine Energy Resources
\end{tabular}} \\
\hline Wave (EEZ) & 320 & 140 & $13,000,000$ & 69 & 3.4 \\
\hline Wave (to $10 \mathrm{nmi}$ ) & 220 & 91 & $8,500,000$ & 45 & 2.2 \\
\hline Tidal & 1.8 & 0.89 & 84,000 & 0.44 & 0.02 \\
\hline \multicolumn{6}{|l|}{$\begin{array}{r}\text { Top } 5 \text { Tidal Sites } \\
\text { Ranked by Power } \\
\end{array}$} \\
\hline San Francisco Bay Entrance, CA & 1.6 & 0.78 & 73,000 & 0.39 & 0.02 \\
\hline Humboldt Bay, CA & 0.12 & 0.06 & 5,800 & 0.03 & 0.00 \\
\hline Heckman Island, CA & 0.05 & 0.03 & 2,500 & 0.01 & 0.00 \\
\hline San Diego Bay, CA & 0.03 & 0.01 & 1,200 & 0.01 & 0.00 \\
\hline Tomales Bay, CA & 0.03 & 0.01 & 1,200 & 0.01 & 0.00 \\
\hline Ocean Current & 0 & 0 & 0 & 0 & 0 \\
\hline Ocean Thermal & not reported & 0 & 0 & 0 & 0 \\
\hline River & 51 & 0.55 & 52,000 & 0.27 & 0.01 \\
\hline $\begin{array}{l}\text { Total (Wave to EEZ + Tidal + Ocean } \\
\text { Current + Ocean Thermal + River) }\end{array}$ & 370 & 140 & $13,000,000$ & 69 & 3.4 \\
\hline $\begin{array}{l}\text { Total (Wave to } 10 \mathrm{nmi}+\text { Tidal + } \\
\text { Ocean Current + Ocean Thermal + } \\
\text { River) }\end{array}$ & 270 & 92 & $8,700,000$ & 46 & 2.2 \\
\hline
\end{tabular}

${ }^{\text {a } A l l}$ values are listed to two significant figures; therefore, totals shown may not equal the sum of values.

${ }^{b}$ Detailed methodologies for estimating Technical Resource are provided in Section 2. 
Table 3b. Theoretical and Technical West Coast Marine Energy Resources for Oregon ${ }^{a}$

\begin{tabular}{|c|c|c|c|c|c|}
\hline & $\begin{array}{r}\text { Theoretical } \\
\text { Resource } \\
(T W h / y r)\end{array}$ & $\begin{array}{r}\text { Technical } \\
\text { Resource }^{b} \\
\text { (TWh/yr) }\end{array}$ & $\begin{array}{r}\text { Technical } \\
\text { Resource as } \\
\text { Potential } \\
\text { Number of } \\
\text { Homes } \\
\text { Powered }\end{array}$ & $\begin{array}{r}\text { Technical } \\
\text { Resource as } \\
\text { Percent of 2019 } \\
\text { Regional } \\
\text { Electricity } \\
\text { Generation in } \\
\text { OR } \\
(62.3 \text { TWh) } \\
(\%)\end{array}$ & $\begin{array}{r}\text { Technical } \\
\text { Resource as } \\
\text { Percent of US } \\
\text { Electricity } \\
\text { Generation } \\
(4126.7 \text { TWh) } \\
(\%)\end{array}$ \\
\hline \multicolumn{6}{|l|}{$\begin{array}{l}\text { Oregon } \\
\text { Marine Energy Resources }\end{array}$} \\
\hline Wave (EEZ) & 170 & 93 & $8,700,000$ & 150 & 2.2 \\
\hline Wave (to $10 \mathrm{nmi}$ ) & 130 & 68 & $6,400,000$ & 110 & 1.6 \\
\hline Tidal & 0.42 & 0.21 & 20,000 & 0.34 & 0.01 \\
\hline \multicolumn{6}{|l|}{$\begin{array}{r}\text { Top } 5 \text { Tidal Sites } \\
\text { Ranked by Power } \\
\end{array}$} \\
\hline Coos Bay Entrance, OR & 0.18 & 0.09 & 8,200 & 0.14 & 0.00 \\
\hline Tillamook Bay Entrance, OR & 0.06 & 0.03 & 2,900 & 0.05 & 0.00 \\
\hline Bandon, OR & 0.04 & 0.02 & 2,100 & 0.04 & 0.00 \\
\hline Yaquina Bay Entrance, OR & 0.04 & 0.02 & 2,100 & 0.04 & 0.00 \\
\hline Winchester Bay Entrance, OR & 0.04 & 0.02 & 1,600 & 0.03 & 0.00 \\
\hline Ocean Current & 0 & 0 & 0 & 0 & 0 \\
\hline Ocean Thermal & not reported & 0 & 0 & 0 & 0 \\
\hline River & 76 & 2.2 & 200,000 & 3.5 & 0.05 \\
\hline $\begin{array}{l}\text { Total (Wave to EEZ + Tidal + Ocean } \\
\text { Current + Ocean Thermal + River) }\end{array}$ & 250 & 95 & $8,900,000$ & 150 & 2.3 \\
\hline $\begin{array}{l}\text { Total (Wave to } 10 \mathrm{nmi}+\text { Tidal + } \\
\text { Ocean Current + Ocean Thermal + } \\
\text { River) }\end{array}$ & 210 & 70 & $6,600,000$ & 110 & 1.7 \\
\hline
\end{tabular}

${ }^{a}$ All values are listed to two significant figures; therefore, totals shown may not equal the sum of values.

${ }^{b}$ Detailed methodologies for estimating Technical Resource are provided in Section 2 
Table 3c. Theoretical and Technical West Coast Marine Energy Resources for Washington ${ }^{a}$

\begin{tabular}{|c|c|c|c|c|c|}
\hline & $\begin{array}{r}\text { Theoretical } \\
\text { Resource } \\
(\mathrm{TWh} / \mathrm{yr})\end{array}$ & $\begin{array}{r}\text { Technical } \\
\text { Resource }^{\mathrm{b}} \\
(\mathrm{TWh} / \mathrm{yr})\end{array}$ & $\begin{array}{r}\text { Technical } \\
\text { Resource as } \\
\text { Potential } \\
\text { Number of } \\
\text { Homes } \\
\text { Powered }\end{array}$ & \begin{tabular}{|r|} 
Technical \\
Resource as \\
Percent of 2019 \\
Regional \\
Electricity \\
Generation in \\
WA \\
$(106.5$ TWh $)$ \\
$(\%)$
\end{tabular} & $\begin{array}{r}\text { Technical } \\
\text { Resource as } \\
\text { Percent of US } \\
\text { Electricity } \\
\text { Generation } \\
\text { (4126.7 TWh) } \\
(\%)\end{array}$ \\
\hline \multicolumn{6}{|l|}{\begin{tabular}{|l|} 
Washington \\
Marine Energy Resources
\end{tabular}} \\
\hline Wave (EEZ) & 13 & 5.4 & 510,000 & 5.1 & 0.13 \\
\hline Wave (to $10 \mathrm{nmi}$ ) & 69 & 36 & $3,400,000$ & 34 & 0.87 \\
\hline Tidal & 6.0 & 3.0 & 280,000 & 2.8 & 0.07 \\
\hline \multicolumn{6}{|l|}{$\begin{array}{r}\text { Top } 5 \text { Tidal Sites } \\
\text { Ranked by Power }\end{array}$} \\
\hline Admiralty Inlet Entrance, WA & 4.0 & 2.0 & 190,000 & 1.9 & 0.05 \\
\hline Willapa Bay, WA & 0.80 & 0.40 & 37,000 & 0.37 & 0.01 \\
\hline Columbia River, WA & 0.61 & 0.31 & 29,000 & 0.29 & 0.01 \\
\hline Grays Harbor, WA & 0.53 & 0.27 & 25,000 & 0.25 & 0.01 \\
\hline $\mathrm{n} / \mathrm{a}$ & 0 & & & & \\
\hline Ocean Current & 0 & 0 & 0 & 0 & 0 \\
\hline Ocean Thermal & not reported & 0 & 0 & 0 & 0 \\
\hline River & 66 & 4.0 & 370,000 & 3.7 & 0.10 \\
\hline $\begin{array}{l}\text { Total (Wave to EEZ + Tidal + Ocean } \\
\text { Current + Ocean Thermal + River) }\end{array}$ & 85 & 12 & $1,200,000$ & 12 & 0.30 \\
\hline $\begin{array}{l}\text { Total (Wave to } 10 \mathrm{nmi}+\text { Tidal + } \\
\text { Ocean Current + Ocean Thermal + } \\
\text { River) }\end{array}$ & 140 & 43 & $4,000,000$ & 40 & 1.0 \\
\hline
\end{tabular}

${ }^{a}$ All values are listed to two significant figures; therefore, totals shown may not equal the sum of values.

${ }^{b}$ Detailed methodologies for estimating Technical Resource are provided in Section 2. 
Table 3d. Theoretical and Technical West Coast Marine Energy Resources for the U.S. West Coast (CA, OR, WA) ${ }^{\text {a }}$

\begin{tabular}{|c|c|c|c|c|c|}
\hline & $\begin{array}{r}\text { Theoretical } \\
\text { Resource } \\
\text { (TWh/yr) }\end{array}$ & $\begin{array}{r}\text { Technical } \\
\text { Resource } \\
\text { (TWh/yr) }\end{array}$ & $\begin{array}{r}\text { Technical } \\
\text { Resource as } \\
\text { Potential } \\
\text { Number of } \\
\text { Homes } \\
\text { Powered } \\
\end{array}$ & $\begin{array}{r}\text { Technical } \\
\text { Resource as } \\
\text { Percent of } 2019 \\
\text { Regional } \\
\text { Electricity } \\
\text { Generation in } \\
\text { CA, OR, WA } \\
(370.5 \text { TWh) } \\
(\%)\end{array}$ & $\begin{array}{r}\text { Technical } \\
\text { Resource as } \\
\text { Percent of US } \\
\text { Electricity } \\
\text { Generation } \\
(4126.7 \text { TWh) } \\
(\%)\end{array}$ \\
\hline \multicolumn{6}{|l|}{$\begin{array}{l}\text { West Coast (CA, OR, WA) } \\
\text { Marine Energy Resources }\end{array}$} \\
\hline Wave (EEZ) & 500 & 240 & $22,000,000$ & 64 & 5.7 \\
\hline Wave (to $10 \mathrm{nmi}$ ) & 420 & 190 & $18,000,000$ & 52 & 4.7 \\
\hline Tidal & 8.2 & 4.1 & 380,000 & 1.1 & 0.10 \\
\hline \multicolumn{6}{|l|}{$\frac{\text { Top } 5 \text { Tidal Sites }}{\text { Ranked by Power }}$} \\
\hline Admiralty Inlet Entrance, WA & 4.0 & 2.0 & 190,000 & 0.54 & 0.05 \\
\hline San Francisco Bay Entrance, CA & 1.6 & 0.78 & 73,000 & 0.21 & 0.02 \\
\hline Willapa Bay, WA & 0.80 & 0.40 & 37,000 & 0.11 & 0.01 \\
\hline Columbia River, WA & 0.61 & 0.31 & 29,000 & 0.08 & 0.01 \\
\hline Grays Harbor, WA & 0.53 & 0.27 & 25,000 & 0.07 & 0.01 \\
\hline Ocean Current & 0 & 0 & 0 & 0 & 0 \\
\hline Ocean Thermal & not reported & 0 & 0 & 0 & 0 \\
\hline River & 190 & 6.7 & 630,000 & 1.8 & 0.16 \\
\hline $\begin{array}{l}\text { Total (Wave to EEZ + Tidal + Ocean } \\
\text { Current + Ocean Thermal + River) } \\
\end{array}$ & 710 & 250 & $23,000,000$ & 67 & 6.0 \\
\hline $\begin{array}{l}\text { Total (Wave to } 10 \mathrm{nmi}+\text { Tidal + } \\
\text { Ocean Current + Ocean Thermal + } \\
\text { River) }\end{array}$ & 620 & 200 & $19,000,000$ & 55 & 5.0 \\
\hline
\end{tabular}

${ }^{a}$ All values are listed to two significant figures; therefore, totals shown may not equal the sum of values.

${ }^{b}$ Detailed methodologies for estimating Technical Resource are provided in Section 2.

\subsection{East Coast}

The East Coast marine energy resources are reported by subregional (New England, MidAtlantic, Southeast) and regional totals (Tables $4 \mathrm{a}-4 \mathrm{~d})$.

The New England Coast subregion includes states from Maine to Connecticut. In New England, the marine energy technical resource total extending to the EEZ is $24 \mathrm{TWh} / \mathrm{yr}$, equivalent to the power needs of 2.3-million homes, 25\% of the subregion's 2019 net electricity generation, or $0.59 \%$ of the total electricity generation by U.S. states in 2019 (Table 4a). The wave resource accounts for $21 \mathrm{TWh} / \mathrm{yr}$ of the $24 \mathrm{TWh} / \mathrm{yr}$ total. The five largest tidal resources in the subregion are located in Maine, including the area east of Cross Island, which is the third-largest tidal site by power in the CONUS. The total technical resource of all tidal sites in this subregion is 3.3 $\mathrm{TWh} / \mathrm{yr}$, providing the potential to power 310,000 homes.

The Mid-Atlantic subregion includes states from New York to Virginia. In the Mid-Atlantic Coast, the marine energy technical resource total extending to the EEZ is $16 \mathrm{TWh} / \mathrm{yr}$, equivalent 
to the power needs of 1.5-million homes, $4.8 \%$ of the subregion's 2019 net electricity generation, or $0.40 \%$ of the total electricity generation by U.S. states in 2019 (Table 4b). The wave resource accounts for $12 \mathrm{TWh} / \mathrm{yr}$ of the $16 \mathrm{TWh} / \mathrm{yr}$ total. The top five tidal sites by power in the MidAtlantic include two locations between Long Island and Fishers Island, New York; Delaware Bay, Delaware/New Jersey; Chesapeake Bay, Virginia; and Toms Cove, Maryland — and have the potential to power 309,000 homes. All of the tidal sites in this subregion have a total technical resource of $3.8 \mathrm{TWh} / \mathrm{yr}$, which could power 360,000 homes.

The Southeastern Coast subregion includes states from North Carolina to Florida. In the Southeastern Coast subregion, the marine energy technical resource total extending to the EEZ is $74 \mathrm{TWh} / \mathrm{yr}$, equivalent to the power needs of 7-million homes, 15\% of the subregion's 2019 net electricity generation, or $1.8 \%$ of the total electricity generation by U.S. states in 2019 (Table 4c). The largest marine energy resource is the ocean current resource with $49 \mathrm{TWh} / \mathrm{yr}$ of technical resource, followed by $22 \mathrm{TWh} / \mathrm{yr}$ in wave resource. The top five tidal sites by power in the Southeastern Coast subregion include two locations in South Carolina and three in Georgia. The technical resource of all of the tidal sites in this subregion is $3.0 \mathrm{TWh} / \mathrm{yr}$, enough to power 280,000 homes. To date, the Southeastern Coast subregion is the only area with resources in all five marine energy resource types. While the OTEC report by Ascari et al. (2012) only reports the total OTEC resource within the EEZ for the East Coast, the report states, “ ... mean net power of $80 \mathrm{MW}$ is achievable as far north as 36 degrees, offshore from North Carolina where the Gulf Stream breaks from the U.S. coast into the Atlantic Ocean."

Overall, the East Coast Region's marine energy technical resource total extending to the EEZ is $460 \mathrm{TWh} / \mathrm{yr}$, equivalent to the power needs of 43-million homes, 49\% of the East Coast's 2019 net electricity generation, or $11 \%$ of the total electricity generation by U.S. states in 2019 (Table 4d). The ocean thermal resource accounts for $340 \mathrm{TWh} / \mathrm{yr}$ of the total marine energy resource.

The wave resource at the edge of the EEZ is $55 \mathrm{TWh} / \mathrm{yr}$. Much of this energy is in waves that are generated within the EEZ by westerly winds and are propagating offshore. On the inner-shelf (10 nmi from shore) the theoretical resource does not exceed the $8 \mathrm{~kW} / \mathrm{m}$ threshold (in the annual average) described in Section 2.2 and, therefore, the technical wave resource is zero. Alternate methodologies for estimating the technical resource, especially a method focused on small-scale wave energy for blue economy applications, could certainly identify viable wave resources here. For example, if the 'outflow energy' in Section 2.2 was lowered from $8 \mathrm{~kW} / \mathrm{m}$ to $5 \mathrm{~kW} / \mathrm{m}$, the East Coast's 10-nmi technical resource would be $3.8 \mathrm{TWh} / \mathrm{yr}$.

The ocean current resource of $49 \mathrm{TWh} / \mathrm{yr}$ in the Gulf Stream is the only such resource in the United States and is the equivalent to powering 4.6-million homes. The top five tidal sites by power include Delaware Bay, Delaware/New Jersey; east of Cross Island, Maine; Fishers Island Sound Central entrance, New York ('The Race'); Chesapeake Bay entrance, Virginia; and Port Royal Sound, South Carolina. All of the tidal sites along the East Coast have a technical resource of $10 \mathrm{TWh} / \mathrm{yr}$. 
Table 4a. Theoretical and Technical East Coast Marine Energy Resources for the New England Coast Subregion ${ }^{a}$

\begin{tabular}{|c|c|c|c|c|c|}
\hline & $\begin{array}{r}\text { Theoretical } \\
\text { Resource } \\
(\mathrm{TWh} / \mathrm{yr})\end{array}$ & $\begin{array}{r}\text { Technical } \\
\text { Resource }^{b} \\
\text { (TWh/yr) }\end{array}$ & $\begin{array}{r}\text { Technical } \\
\text { Resource as } \\
\text { Potential } \\
\text { Number of } \\
\text { Homes } \\
\text { Powered }\end{array}$ & \begin{tabular}{|} 
Technical \\
Resource as \\
Percent of 2019 \\
Regional \\
Electricity \\
Generation in \\
ME, NH, MA, RI, \\
$\mathrm{CT}$ \\
$(97.7$ TWh $)$ \\
$(\%)$
\end{tabular} & $\begin{array}{r}\text { Technical } \\
\text { Resource as } \\
\text { Percent of US } \\
\text { Electricity } \\
\text { Generation } \\
\text { (4126.7 TWh) } \\
(\%)\end{array}$ \\
\hline \multicolumn{6}{|l|}{$\begin{array}{l}\text { New England } \\
\text { (Maine-Connecticut) } \\
\text { Marine Energy Resources }\end{array}$} \\
\hline Wave (EEZ) & 80 & 21 & $2,000,000$ & 21 & 0.51 \\
\hline Wave (to $10 \mathrm{nmi}$ ) & 34 & 0 & 0 & 0 & 0 \\
\hline Tidal & 6.6 & 3.3 & 310,000 & 3.4 & 0.08 \\
\hline \multicolumn{6}{|l|}{$\begin{array}{r}\text { Top } 5 \text { New England (ME-CT) Tidal } \\
\text { Sites Ranked by Power }\end{array}$} \\
\hline E of Cross Island, ME & 2.4 & 1.2 & 110,000 & 1.2 & 0.03 \\
\hline S of Eastport, ME & 0.93 & 0.46 & 44,000 & 0.48 & 0.01 \\
\hline $\begin{array}{r}\begin{array}{r}\text { Btwn Southwest Breaker \& Green } \\
\text { Islands, ME }\end{array} \\
\end{array}$ & 0.60 & 0.30 & 28,000 & 0.30 & 0.01 \\
\hline $\begin{array}{r}\text { Btwn East Sister \& } \\
\text { Crow Islands, ME }\end{array}$ & 0.53 & 0.27 & 25,000 & 0.27 & 0.01 \\
\hline NE of Roque Island, ME & 0.28 & 0.14 & 13,000 & 0.14 & 0.00 \\
\hline Ocean Current & 0 & 0 & 0 & 0 & 0 \\
\hline Ocean Thermal & & & & & not reported \\
\hline River & 13 & 0.12 & 11,000 & 0.12 & 0.00 \\
\hline \multicolumn{6}{|l|}{ River Resource by State } \\
\hline Connecticut & 0.93 & 0.04 & 3,500 & 0.04 & 0.00 \\
\hline Maine & 9.4 & 0.05 & 4,400 & 0.05 & 0.00 \\
\hline Massachusetts & 1.3 & 0.03 & 2,600 & 0.03 & 0.00 \\
\hline New Hampshire & 1.8 & 0.01 & 690 & 0.01 & 0.00 \\
\hline Rhode Island & 0.00 & 0 & 0 & 0 & 0 \\
\hline $\begin{array}{l}\text { Total (Wave to EEZ + Tidal + } \\
\text { Ocean Current + Ocean } \\
\text { Thermal + River) }\end{array}$ & 100 & 24 & $2,300,000$ & 25 & 0.59 \\
\hline $\begin{array}{l}\text { Total (Wave to } 10 \mathrm{nmi}+\text { Tidal + } \\
\text { Ocean Current + Ocean } \\
\text { Thermal + River) }\end{array}$ & 54 & 3.4 & 320,000 & 3.5 & 0.08 \\
\hline
\end{tabular}

${ }^{a}$ All values are listed to two significant figures; therefore, totals shown may not equal the sum of values.

${ }^{b}$ Detailed methodologies for estimating Technical Resource are provided in Section 2. 
Table 4b. Theoretical and Technical East Coast Marine Energy Resources for the Mid-Atlantic Subregion ${ }^{a}$

\begin{tabular}{|c|c|c|c|c|c|}
\hline & $\begin{array}{r}\text { Theoretical } \\
\text { Resource } \\
(\mathrm{TWh} / \mathrm{yr})\end{array}$ & $\begin{array}{r}\text { Technical } \\
\text { Resource }^{\mathrm{b}} \\
(\mathrm{TWh} / \mathrm{yr})\end{array}$ & $\begin{array}{r}\text { Technical } \\
\text { Resource as } \\
\text { Potential } \\
\text { Number of } \\
\text { Homes } \\
\text { Powered }\end{array}$ & \begin{tabular}{|} 
Technical \\
Resource as \\
Percent of 2019 \\
Regional \\
Electricity \\
Generation in \\
NY, NJ, DE, MD, \\
VA \\
$(344.0$ TWh \\
$(\%)$
\end{tabular} & $\begin{array}{r}\text { Technical } \\
\text { Resource as } \\
\text { Percent of US } \\
\text { Electricity } \\
\text { Generation } \\
(4126.7 \text { TWh) } \\
(\%)\end{array}$ \\
\hline \multicolumn{6}{|l|}{$\begin{array}{l}\text { Mid-Atlantic } \\
\text { (New York-Virginia) } \\
\text { Marine Energy Resources }\end{array}$} \\
\hline Wave (EEZ) & 67 & 12 & $1,200,000$ & 3.6 & 0.30 \\
\hline Wave (to $10 \mathrm{nmi}$ ) & 23 & 0 & 0 & 0 & 0 \\
\hline \begin{tabular}{|l} 
Tidal \\
\end{tabular} & 7.6 & 3.8 & 360,000 & 1.1 & 0.09 \\
\hline \multicolumn{6}{|l|}{$\begin{array}{r}\text { Top } 5 \text { Mid-Atlantic (NY-VA) Tidal } \\
\text { Sites Ranked by Power }\end{array}$} \\
\hline $\begin{array}{l}\text { Fishers Island Sound } \\
\text { Central Entrance, NY }\end{array}$ & 2.1 & 1.1 & 100,000 & 0.31 & 0.03 \\
\hline Delaware Bay, DE/NJ & 2.8 & 1.4 & 130,000 & 0.40 & 0.03 \\
\hline $\begin{array}{r}\text { Chesapeake Bay } \\
\text { Entrance, VA }\end{array}$ & 1.1 & 0.57 & 53,000 & 0.17 & 0.01 \\
\hline Toms Cove, MD & 0.29 & 0.14 & 14,000 & 0.04 & 0.00 \\
\hline $\begin{array}{r}\text { Fishers Island Sound } \\
\text { Southern Entrance, NY }\end{array}$ & 0.25 & 0.12 & 12,000 & 0.04 & 0.00 \\
\hline Ocean Current & 0 & 0 & 0 & 0 & 0 \\
\hline Ocean Thermal & & & & & not reported \\
\hline River & 20 & 0.17 & 16,000 & 0.05 & 0.00 \\
\hline \multicolumn{6}{|l|}{ River Resource by State } \\
\hline Delaware & 0.09 & 0.01 & 610 & 0.00 & 0.00 \\
\hline Maryland & 2.0 & 0.04 & 4,100 & 0.01 & 0.00 \\
\hline New Jersey & 1.7 & 0.03 & 2,900 & 0.01 & 0.00 \\
\hline New York & 8.7 & 0.06 & 5,100 & 0.02 & 0.00 \\
\hline Virginia & 7.5 & 0.03 & 3,200 & 0.01 & 0.00 \\
\hline $\begin{array}{l}\text { Total (Wave to EEZ + Tidal + } \\
\text { Ocean Current + Ocean } \\
\text { Thermal + River) }\end{array}$ & 95 & 16 & $1,500,000$ & 4.8 & 0.40 \\
\hline $\begin{array}{l}\text { Total (Wave to } 10 \mathrm{nmi}+\text { Tidal + } \\
\text { Ocean Current + Ocean } \\
\text { Thermal + River) }\end{array}$ & 51 & 4.0 & 370,000 & 1.2 & 0.10 \\
\hline
\end{tabular}

${ }^{a}$ All values are listed to two significant figures; therefore, totals shown may not equal the sum of values.

${ }^{b}$ Detailed methodologies for estimating Technical Resource are provided in Section 2. 
Table 4c. Theoretical and Technical East Coast Marine Energy Resources for the Southeastern Coast Subregion ${ }^{a}$

\begin{tabular}{|c|c|c|c|c|c|}
\hline & $\begin{array}{r}\text { Theoretical } \\
\text { Resource } \\
(\mathrm{TWh} / \mathrm{yr})\end{array}$ & $\begin{array}{r}\text { Technical } \\
\text { Resource }^{b} \\
\text { (TWh/yr) }\end{array}$ & $\begin{array}{r}\text { Technical } \\
\text { Resource as } \\
\text { Potential } \\
\text { Number of } \\
\text { Homes } \\
\text { Powered }\end{array}$ & \begin{tabular}{|r|} 
Technical \\
Resource as \\
Percent of 2019 \\
Regional \\
Electricity \\
Generation in \\
NC, SC, GA, \\
$1 / 2 \mathrm{FL}$ \\
$(482.8 \mathrm{TWh})$ \\
$(\%)$
\end{tabular} & $\begin{array}{r}\text { Technical } \\
\text { Resource as } \\
\text { Percent of US } \\
\text { Electricity } \\
\text { Generation } \\
(4126.7 \mathrm{TWh}) \\
(\%)\end{array}$ \\
\hline \multicolumn{6}{|l|}{$\begin{array}{l}\text { Southeast } \\
\text { (North Carolina-Florida) } \\
\text { Marine Energy Resources }\end{array}$} \\
\hline Wave (EEZ) & 140 & 22 & $2,000,000$ & 4.5 & 0.53 \\
\hline Wave (to $10 \mathrm{nmi}$ ) & 40 & 0 & 0 & 0 & 0 \\
\hline Tidal & 6.0 & 3.0 & 280,000 & 0.62 & 0.07 \\
\hline \multicolumn{6}{|l|}{$\begin{array}{c}\text { Top } 5 \text { Southeast Coast (NC-FL) } \\
\text { Tidal Sites Ranked by Power }\end{array}$} \\
\hline Port Royal Sound, SC & 0.95 & 0.48 & 45,000 & 0.10 & 0.01 \\
\hline Saint Helena Sound, SC & 0.89 & 0.45 & 42,000 & 0.09 & 0.01 \\
\hline Sapelo Sound, GA & 0.41 & 0.21 & 19,000 & 0.04 & 0.00 \\
\hline St Catherines Sound, GA & 0.39 & 0.19 & 18,000 & 0.04 & 0.00 \\
\hline $\begin{array}{r}\text { Cumberland Sound } \\
\text { Entrance, GA } \\
\end{array}$ & 0.27 & 0.14 & 13,000 & 0.03 & 0.00 \\
\hline Ocean Current & 160 & 49 & $4,600,000$ & 10 & 1.2 \\
\hline Ocean Thermal & & & & & not reported \\
\hline River & 24 & 0.38 & 36,000 & 0.08 & 0.01 \\
\hline \multicolumn{6}{|l|}{ River Resource by State } \\
\hline Florida & 3.1 & 0.10 & 9,500 & 0.02 & 0.00 \\
\hline Georgia & 8.5 & 0.11 & 10,000 & 0.02 & 0.00 \\
\hline North Carolina & 5.9 & 0.02 & 2,000 & 0.00 & 0.00 \\
\hline South Carolina & 6.6 & 0.15 & 14,000 & 0.03 & 0.00 \\
\hline $\begin{array}{l}\text { Total (Wave to EEZ + Tidal + } \\
\text { Ocean Current + Ocean } \\
\text { Thermal + River) }\end{array}$ & 330 & 74 & $7,000,000$ & 15 & 1.8 \\
\hline $\begin{array}{l}\text { Total (Wave to } 10 \mathrm{nmi}+\text { Tidal + } \\
\text { Ocean Current + Ocean } \\
\text { Thermal + River) }\end{array}$ & 230 & 52 & $4,900,000$ & 11 & 1.3 \\
\hline
\end{tabular}

${ }^{a}$ All values are listed to two significant figures; therefore, totals shown may not equal the sum of values.

${ }^{b}$ Detailed methodologies for estimating Technical Resource are provided in Section 2. 
Table 4d. Theoretical and Technical East Coast Marine Energy Resources for the East Coast Region ${ }^{a}$

\begin{tabular}{|c|c|c|c|c|c|}
\hline & $\begin{array}{r}\text { Theoretical } \\
\text { Resource } \\
\text { (TWh/yr) }\end{array}$ & $\begin{array}{r}\text { Technical } \\
\text { Resource } \\
(\mathrm{TWh} / \mathrm{yr}) \\
\end{array}$ & $\begin{array}{r}\text { Technical } \\
\text { Resource as } \\
\text { Potential } \\
\text { Number of } \\
\text { Homes } \\
\text { Powered } \\
\end{array}$ & $\begin{array}{r}\text { Technical } \\
\text { Resource as } \\
\text { Percent of } 2019 \\
\text { Regional } \\
\text { Electricity } \\
\text { Generation in } \\
\text { ME to FL as } \\
\text { listed above } \\
(924.5 \text { TWh) } \\
(\%) \\
\end{array}$ & $\begin{array}{r}\text { Technical } \\
\text { Resource as } \\
\text { Percent of US } \\
\text { Electricity } \\
\text { Generation } \\
(4126.7 \text { TWh }) \\
(\%) \\
\end{array}$ \\
\hline \multicolumn{6}{|l|}{\begin{tabular}{|l|} 
East Coast \\
(Maine-Florida) \\
Marine Energy Resources \\
\end{tabular}} \\
\hline Wave (EEZ) & 280 & 55 & $5,200,000$ & 6.0 & 1.3 \\
\hline Wave (to $10 \mathrm{nmi}$ ) & 98 & 0 & 0 & 0 & 0 \\
\hline Tidal & 20 & 10 & 950,000 & 1.1 & 0.24 \\
\hline \multicolumn{6}{|l|}{$\begin{array}{r}\text { Top } 5 \text { East Coast Tidal Sites } \\
\text { Ranked by Power } \\
\end{array}$} \\
\hline Delaware Bay, DE/NJ & 2.8 & 1.4 & 130,000 & 0.15 & 0.03 \\
\hline $\mathrm{E}$ of Cross Island, $\mathrm{ME}$ & 2.4 & 1.2 & 110,000 & 0.13 & 0.03 \\
\hline $\begin{array}{l}\text { Fishers Island Sound } \\
\text { Central Entrance, NY }\end{array}$ & 2.1 & 1.1 & 100,000 & 0.12 & 0.03 \\
\hline Chesapeake Bay & 11 & 0.57 & 53000 & 006 & 0.1 \\
\hline Port Royal Sound, SC & 0.95 & 0.48 & 45,000 & 0.05 & 0.01 \\
\hline Ocean Current & 160 & 49 & $4,600,000$ & 5.3 & 1.2 \\
\hline Ocean Thermal & not reported & 340 & $32,000,000$ & 37 & 8.3 \\
\hline River & 57 & 0.67 & 63,000 & 0.07 & 0.02 \\
\hline $\begin{array}{l}\text { Total (Wave to EEZ + Tidal + } \\
\text { Ocean Current + Ocean } \\
\text { Thermal + River) }\end{array}$ & 520 & 460 & $43,000,000$ & 49 & 11 \\
\hline $\begin{array}{l}\text { Total (Wave to } 10 \mathrm{nmi}+\text { Tidal + } \\
\text { Ocean Current + Ocean } \\
\text { Thermal + River) }\end{array}$ & 800 & 400 & $38,000,000$ & 43 & 9.7 \\
\hline
\end{tabular}

${ }^{a} A$ Il values are listed to two significant figures; therefore, totals shown may not equal the sum of values.

${ }^{b}$ Detailed methodologies for estimating Technical Resource are provided in Section 2.

\subsection{Gulf Coast}

The Gulf of Mexico Coast marine energy resources are reported by regional total (Table 5).

The Gulf Coast Region's marine energy technical resource total extending to the EEZ is 84 $\mathrm{TWh} / \mathrm{yr}$, equivalent to the power needs of 7.9-million homes, $9.2 \%$ of the Gulf Coast's 2019 net electricity generation, or $2.0 \%$ of the total electricity generation by U.S. states in 2019 . The ocean thermal resource accounts for $53 \mathrm{TWh} / \mathrm{yr}$ of the total marine energy resource, and the river hydrokinetic resource contributes $31 \mathrm{TWh} / \mathrm{yr}$. The top five tidal sites by power along the Gulf Coast include four locations in the Florida Keys and one in Pelican Bay, Alabama. Combined, the tidal sites in this subregion have a total technical resource of $0.37 \mathrm{TWh} / \mathrm{yr}$, equivalent to the power needed by 35,000 homes. There are no wave or ocean current technical resources in this 
region. There is a theoretical wave resource in the Gulf, but in the annual-average, this resource does not exceed the $8-\mathrm{kW} / \mathrm{m}$ threshold described in Section 2.2 and, therefore, the technical wave resource is zero. Alternate methodologies for estimating the technical resource, especially a method focused on small-scale wave energy for blue economy applications, could certainly identify viable wave resources.

Table 5. Theoretical and Technical Gulf of Mexico Coast Marine Energy Resources ${ }^{a}$

\begin{tabular}{|c|c|c|c|c|c|}
\hline & $\begin{array}{r}\text { Theoretical } \\
\text { Resource } \\
(\mathrm{TWh} / \mathrm{yr})\end{array}$ & $\begin{array}{r}\text { Technical } \\
\text { Resource }^{\mathrm{b}} \\
(\mathrm{TWh} / \mathrm{yr}) \\
\end{array}$ & $\begin{array}{r}\text { Technical } \\
\text { Resource as } \\
\text { Potential } \\
\text { Number of } \\
\text { Homes } \\
\text { Powered }\end{array}$ & \begin{tabular}{|} 
Technical \\
Resource as \\
Percent of 2019 \\
Regional \\
Electricity \\
Generation \\
$(914.8$ TWh) \\
$(\%)$
\end{tabular} & $\begin{array}{r}\text { Technical } \\
\text { Resource as } \\
\text { Percent of US } \\
\text { Electricity } \\
\text { Generation } \\
\text { (4126.7 TWh) } \\
(\%)\end{array}$ \\
\hline \multicolumn{6}{|l|}{\begin{tabular}{|l|} 
Gulf Coast \\
Marine Energy Resources
\end{tabular}} \\
\hline Wave (EEZ) & 69 & 0 & 0 & 0 & 0 \\
\hline Wave (to $10 \mathrm{nmi}$ ) & 27 & 0 & 0 & 0 & 0 \\
\hline Tidal & 0.74 & 0.37 & 35,000 & 0.04 & 0.01 \\
\hline \multicolumn{6}{|l|}{$\begin{array}{r}\text { Top } 5 \text { Tidal Sites } \\
\text { Ranked by Power } \\
\end{array}$} \\
\hline Btwn Boca Grande \& Gull Keys, FL & 0.25 & 0.12 & 12,000 & 0.01 & 0.00 \\
\hline W of Pigeon Key, FL & 0.14 & 0.07 & 6,600 & 0.01 & 0.00 \\
\hline $\mathrm{N}$ of Egmont Key, $\mathrm{FL}$ & 0.11 & 0.06 & 5,300 & 0.01 & 0.00 \\
\hline E of Key West, FL & 0.11 & 0.05 & 4,900 & 0.01 & 0.00 \\
\hline Pelican Bay, AL & 0.06 & 0.03 & 2,900 & 0.00 & 0.00 \\
\hline Ocean Current & 0 & 0 & 0 & 0 & 0 \\
\hline Ocean Thermal & not reported & 53 & $5,000,000$ & 5.8 & 1.3 \\
\hline River & 170 & 31 & $2,900,000$ & 3.3 & 0.74 \\
\hline \multicolumn{6}{|l|}{ River Resource by State } \\
\hline Alabama & 15 & 0.81 & 76,000 & 0.09 & 0.02 \\
\hline Louisiana & 75 & 17 & $1,600,000$ & 1.9 & 0.42 \\
\hline Mississippi & 56 & 12 & $1,200,000$ & 1.4 & 0.30 \\
\hline Texas & 29 & 0.26 & 24,000 & 0.03 & 0.01 \\
\hline $\begin{array}{l}\text { Total (Wave to EEZ + Tidal + Ocean } \\
\text { Current + Ocean Thermal + River) }\end{array}$ & 240 & 84 & $7,900,000$ & 9.2 & 2.0 \\
\hline $\begin{array}{l}\text { Total (Wave to } 10 \mathrm{nmi}+\text { Tidal + } \\
\text { Ocean Current + Ocean Thermal + } \\
\text { River) }\end{array}$ & 200 & 84 & $7,900,000$ & 9.2 & 2.0 \\
\hline
\end{tabular}

${ }^{a} A l l$ values are listed to two significant figures; therefore, totals shown may not equal the sum of values.

${ }^{b}$ Detailed methodologies for estimating Technical Resource are provided in Section 2.

\subsection{Alaska}

Alaska's marine energy resources are reported by state total (Table 6).

Alaska's marine energy technical resource total extending to the EEZ is 1,100 TWh/yr, equivalent to the power needs of 100-million homes, which is 180 times Alaska's 2019 net electricity generation, or $27 \%$ of the total electricity generation by U.S. states in 2019 . The wave resource accounts for $890 \mathrm{TWh} / \mathrm{yr}$ and is $62 \%$ of the U.S. wave resource. Alaska's tidal resource of $210 \mathrm{TWh} / \mathrm{yr}$ represents $93 \%$ of the U.S. tidal resource. The top two tidal sites by power, Cook 
Inlet and Chatham Straight, account for 64\% of Alaska's total tidal resource and are relatively close to Anchorage and Juneau, respectively. The state's river hydrokinetic resource of 21

$\mathrm{TWh} / \mathrm{yr}$ is equivalent to the power needed by 1.9 -million homes. There are no ocean current or ocean thermal resources in this region.

Table 6. Theoretical and Technical Alaska Marine Energy Resources ${ }^{a}$

\begin{tabular}{|c|c|c|c|c|c|}
\hline & $\begin{array}{r}\text { Theoretical } \\
\text { Resource } \\
(\mathrm{TWh} / \mathrm{yr})\end{array}$ & $\begin{array}{r}\text { Technical } \\
\text { Resource }^{\mathrm{b}} \\
(\mathrm{TWh} / \mathrm{yr}) \\
\end{array}$ & $\begin{array}{r}\text { Technical } \\
\text { Resource as } \\
\text { Potential } \\
\text { Number of } \\
\text { Homes } \\
\text { Powered }\end{array}$ & $\begin{array}{r}\text { Technical } \\
\text { Resource as } \\
\text { Percent of 2019 } \\
\text { Regional } \\
\text { Electricity } \\
\text { Generation } \\
(6.1 \text { TWh }) \\
(\%)\end{array}$ & $\begin{array}{r}\text { Technical } \\
\text { Resource as } \\
\text { Percent of US } \\
\text { Electricity } \\
\text { Generation } \\
(4126.7 \text { TWh) } \\
(\%)\end{array}$ \\
\hline \multicolumn{6}{|l|}{\begin{tabular}{|l|} 
Alaska \\
Marine Energy Resources \\
\end{tabular}} \\
\hline Wave (EEZ) & 2,000 & 890 & $83,000,000$ & 15,000 & 21 \\
\hline Wave (to $10 \mathrm{nmi}$ ) & 1,200 & 540 & $50,000,000$ & 8,800 & 13 \\
\hline Tidal & 420 & 210 & $20,000,000$ & 3,400 & 5.0 \\
\hline \multicolumn{6}{|l|}{$\begin{array}{l}\text { Top } 10 \text { Tidal Sites } \\
\text { Ranked by Power }\end{array}$} \\
\hline Cook Inlet & 160 & 80 & $7,500,000$ & 1,300 & 1.9 \\
\hline Chatham Strait & 110 & 53 & $5,000,000$ & 860 & 1.3 \\
\hline Clarence Strait & 36 & 18 & $1,700,000$ & 290 & 0.44 \\
\hline Summer Strait & 23 & 12 & $1,100,000$ & 190 & 0.28 \\
\hline $\mathrm{N}$ of Inian Islands & 22 & 11 & $1,100,000$ & 180 & 0.27 \\
\hline Btwn Seguam and Amlia Islands & 10 & 5.1 & 480,000 & 84 & 0.12 \\
\hline Btwn Sundstrom and Sitkinak Islands & 5.5 & 2.8 & 260,000 & 45 & 0.07 \\
\hline NE of Warren Island & 4.7 & 2.3 & 220,000 & 38 & 0.06 \\
\hline Btwn Unalga and Kavalga Islands & 3.8 & 1.9 & 180,000 & 31 & 0.05 \\
\hline Btwn Kagalaska and Adak Islands & 3.7 & 1.9 & 170,000 & 30 & 0.05 \\
\hline Ocean Current & 0 & 0 & 0 & 0 & 0 \\
\hline \begin{tabular}{|l} 
Ocean Thermal \\
\end{tabular} & 0 & 0 & 0 & 0 & 0 \\
\hline River & 240 & 21 & $1,900,000$ & 340 & 0.50 \\
\hline $\begin{array}{l}\text { Total (Wave to EEZ + Tidal + Ocean } \\
\text { Current + Ocean Thermal + River) } \\
\end{array}$ & 2,700 & 1,100 & $100,000,000$ & 18,000 & 27 \\
\hline $\begin{array}{l}\text { Total (Wave to } 10 \mathrm{nmi}+\text { Tidal + } \\
\text { Ocean Current + Ocean Thermal + } \\
\text { River) }\end{array}$ & 1,800 & 770 & $72,000,000$ & 13,000 & 19 \\
\hline
\end{tabular}

${ }^{a}$ All values are listed to two significant figures; therefore, totals shown may not equal the sum of values.

${ }^{b}$ Detailed methodologies for estimating Technical Resource are provided in Section 2. 


\subsection{Hawaii}

Hawaii's marine energy resources are reported by state total (Table 7).

Hawaii's marine energy technical resource total extending to the EEZ is $390 \mathrm{TWh} / \mathrm{yr}$, equivalent to the power needs of 37 -million homes, $4,000 \%$ of the region's 2019 net electricity generation, or $9.4 \%$ of the total electricity generation by U.S. states in 2019 . The wave resource accounts for $250 \mathrm{TWh} / \mathrm{yr}$, and the ocean thermal resource accounts for the remaining $140 \mathrm{TWh} / \mathrm{yr}$. There is no ocean current resource in Hawaii, and tidal current and river current resources have not been assessed.

Table 7. Theoretical and Technical Hawaii Marine Energy Resources ${ }^{a}$

\begin{tabular}{|c|c|c|c|c|c|}
\hline & $\begin{array}{r}\text { Theoretical } \\
\text { Resource } \\
\text { (TWh/yr) }\end{array}$ & $\begin{array}{r}\text { Technical } \\
\text { Resource }^{\mathrm{b}} \\
(\mathrm{TWh} / \mathrm{yr})\end{array}$ & $\begin{array}{r}\text { Technical } \\
\text { Resource as } \\
\text { Potential } \\
\text { Number of } \\
\text { Homes } \\
\text { Powered }\end{array}$ & $\begin{array}{r}\text { Technical } \\
\text { Resource as } \\
\text { Percent of } 2019 \\
\text { Regional } \\
\text { Electricity } \\
\text { Generation } \\
(9.7 \text { TWh) } \\
(\%)\end{array}$ & $\begin{array}{r}\text { Technical } \\
\text { Resource as } \\
\text { Percent of US } \\
\text { Electricity } \\
\text { Generation } \\
\text { (4126.7 TWh } \\
(\%)\end{array}$ \\
\hline \multicolumn{6}{|l|}{\begin{tabular}{|l} 
Hawaii \\
Marine Energy Resources
\end{tabular}} \\
\hline Wave (EEZ) & 380 & 250 & $23,000,000$ & 2,500 & 6.0 \\
\hline Wave (to $10 \mathrm{nmi}$ ) & 120 & 36 & $3,400,000$ & 370 & 0.87 \\
\hline Tidal & \multicolumn{5}{|r|}{ not assessed } \\
\hline \begin{tabular}{|l|} 
Ocean Current \\
\end{tabular} & 0 & 0 & 0 & 0 & 0 \\
\hline Ocean Thermal & not reported & 140 & $13,000,000$ & 1,500 & 3.5 \\
\hline River & \multicolumn{5}{|r|}{ not assessed } \\
\hline $\begin{array}{l}\text { Total (Wave to EEZ + Tidal + Ocean } \\
\text { Current + Ocean Thermal + River) }\end{array}$ & 380 & 390 & $37,000,000$ & 4,000 & 9.4 \\
\hline $\begin{array}{l}\text { Total (Wave to } 10 \mathrm{nmi}+\text { Tidal + } \\
\text { Ocean Current + Ocean Thermal + } \\
\text { River) }\end{array}$ & 120 & 180 & $17,000,000$ & 1,800 & 4.3 \\
\hline
\end{tabular}

${ }^{a} A$ All values are listed to two significant figures; therefore, totals shown may not equal the sum of values.

${ }^{b}$ Detailed methodologies for estimating Technical Resource are provided in Section 2.

\subsection{Puerto Rico and the U.S. Virgin Islands}

Puerto Rico and the U.S. Virgin Islands' marine energy resources are reported by state total (Table 8).

Puerto Rico and the U.S. Virgin Islands' marine energy technical resource total extending to the EEZ is $38 \mathrm{TWh} / \mathrm{yr}$, equivalent to the power needs of 3.6-million homes, $210 \%$ of the region's 2019 net electricity generation, or $0.92 \%$ of the total electricity generation by U.S. states in 2019 . The ocean thermal resource accounts for all of the identified marine energy resources because there is no technical wave resource in this region; tidal current, ocean current, and river current resources have not been assessed. There is a theoretical wave resource available for these U.S. Territories, but in the annual-average, this resource does not exceed the $8-\mathrm{kW} / \mathrm{m}$ threshold described in Section 2.2 and, therefore, the technical wave resource is zero. Alternate 
methodologies for estimating the technical resource, especially a method focused on small-scale wave energy for blue economy applications, could certainly identify viable wave resources here.

Table 8. Theoretical and Technical Puerto Rico and U.S. Virgin Islands Marine Energy Resources ${ }^{\mathrm{a}}$

\begin{tabular}{|c|c|c|c|c|c|}
\hline & $\begin{array}{r}\text { Theoretical } \\
\text { Resource } \\
(\mathrm{TWh} / \mathrm{yr})\end{array}$ & $\begin{array}{r}\text { Technical } \\
\text { Resource }^{b} \\
\text { (TWh/yr) }\end{array}$ & $\begin{array}{r}\text { Technical } \\
\text { Resource as } \\
\text { Potential } \\
\text { Number of } \\
\text { Homes } \\
\text { Powered }\end{array}$ & $\begin{array}{r}\text { Technical } \\
\text { Resource as } \\
\text { Percent of 2017 } \\
\text { Regional } \\
\text { Electricity } \\
\text { Generation } \\
(18 \text { TWh }) \\
(\%)\end{array}$ & $\begin{array}{r}\text { Technical } \\
\text { Resource as } \\
\text { Percent of US } \\
\text { Electricity } \\
\text { Generation } \\
(4126.7 \text { TWh) } \\
(\%)\end{array}$ \\
\hline \multicolumn{6}{|l|}{$\begin{array}{l}\text { Puerto Rico \& } \\
\text { US Virgin Islands } \\
\text { Marine Energy Resources } \\
\end{array}$} \\
\hline Wave (EEZ) & 16 & 0 & 0 & 0 & 0 \\
\hline Wave (to $10 \mathrm{nmi}$ ) & 18 & 0 & 0 & 0 & 0 \\
\hline Tidal & & & & & not assessed \\
\hline Ocean Current & & & & & not assessed \\
\hline Ocean Thermal & not reported & 38 & $3,600,000$ & 210 & 0.92 \\
\hline River & & & & & not assessed \\
\hline $\begin{array}{l}\text { Total (Wave to EEZ + Tidal + } \\
\text { Ocean Current + Ocean } \\
\text { Thermal + River) } \\
\end{array}$ & 16 & 38 & $3,600,000$ & 210 & 0.92 \\
\hline $\begin{array}{l}\text { Total (Wave to } 10 \mathrm{nmi}+\text { Tidal + } \\
\text { Ocean Current + Ocean } \\
\text { Thermal + River) }\end{array}$ & 18 & 38 & $3,600,000$ & 210 & 0.92 \\
\hline
\end{tabular}

${ }^{a}$ All values are listed to two significant figures; therefore, totals shown may not equal the sum of values.

${ }^{b}$ Detailed methodologies for estimating Technical Resource are provided in Section 2.

\subsection{Pacific Territories and Freely Associated States}

The U.S. Pacific territories and freely associated states' marine energy resources are reported by regional total (Table 9).

Only ocean thermal resources have been assessed for U.S. Pacific territories and freely associated states. The technical ocean thermal resource of this region contributes $63 \%$ of the total marine energy resource for all U.S. states, territories, and freely associated states, with a resource equivalent to power 380-million homes and meet $98 \%$ of the U.S. states' 2019 net electricity generation. Several of these territories and freely associated states are uninhabited and, those that are inhabited, often have limited electrical infrastructure compared to other U.S. states, territories, and freely associated states. Incorporating OTEC and/or seawater for cooling into the U.S. Pacific territories and freely associated states could vastly improve the lives of residents and provide strategic energy sources for trans-Pacific ship refueling needs if OTEC were used to power hydrogen or similar fuel generation and storage.

Though the wave energy resource of the U.S. Pacific territories and freely associated states has not been quantified in detail, there is anecdotal evidence that a significant wave resource exists at many of these sites. For example, a wave buoy near American Samoa has measured an average 
wave resource of more than $20 \mathrm{~kW} / \mathrm{m}$ over the last 3 years, and buoys in Guam and the Northern Mariana Islands have registered a wave resource of $16 \mathrm{~kW} / \mathrm{m}$ to $18 \mathrm{~kW} / \mathrm{m} .{ }^{8}$ PNNL is in the process of running a high-resolution wave model of this region, and an assessment of the total wave resource available there will be conducted as soon as the model runs are complete. The wave resource for this region will, therefore, be included in future work similar to this one.

${ }^{8}$ Data from CDIP, Scripps Institution of Oceanography. Buoy numbers 189, 196, and 197. 
Table 9. Theoretical and Technical Pacific Territories and Freely Associated States Marine Energy Resources ${ }^{a}$

\begin{tabular}{|c|c|c|c|c|c|}
\hline & $\begin{array}{r}\text { Theoretical } \\
\text { Resource } \\
(\mathrm{TWh} / \mathrm{yr})\end{array}$ & $\begin{array}{r}\text { Technical } \\
\text { Resource }^{b} \\
(T W h / y r)\end{array}$ & $\begin{array}{r}\text { Technical } \\
\text { Resource as } \\
\text { Potential } \\
\text { Number of } \\
\text { Homes } \\
\text { Powered } \\
\end{array}$ & \begin{tabular}{|r|} 
Technical \\
Resource as \\
Percent of 2019 \\
Regional \\
Electricity \\
Generation \\
(N/A) \\
$(\%)$ \\
\end{tabular} & $\begin{array}{r}\text { Technical } \\
\text { Resource as } \\
\text { Percent of US } \\
\text { Electricity } \\
\text { Generation } \\
(4126.7 \text { TWh) } \\
(\%)\end{array}$ \\
\hline \multicolumn{6}{|l|}{$\begin{array}{l}\text { Pacific Territories and Freely } \\
\text { Associated States } \\
\text { Marine Energy Resources } \\
\end{array}$} \\
\hline Wave (EEZ) & \multicolumn{5}{|r|}{ not assessed } \\
\hline Wave (to $10 \mathrm{nmi}$ ) & \multicolumn{5}{|r|}{ not assessed } \\
\hline Tidal & \multicolumn{5}{|r|}{ not assessed } \\
\hline Ocean Current & \multicolumn{5}{|r|}{ not assessed } \\
\hline Ocean Thermal & not reported & 4,100 & $380,000,000$ & & 98 \\
\hline \multicolumn{6}{|l|}{ Resource by Locale } \\
\hline Johnson Atoll & not reported & 36 & $3,400,000$ & & 0.87 \\
\hline Wake Island & not reported & 38 & $3,600,000$ & & 0.92 \\
\hline Palmyra & not reported & 95 & $8,900,000$ & & 2.3 \\
\hline Mariana Islands & not reported & 140 & $13,000,000$ & & 3.3 \\
\hline Jarvis Island & not reported & 210 & $20,000,000$ & & 5.2 \\
\hline Howland Island & not reported & 260 & $25,000,000$ & & 6.3 \\
\hline Marshall Island & not reported & 380 & $35,000,000$ & & 9.2 \\
\hline Palau & not reported & 440 & $41,000,000$ & & 11 \\
\hline Micronesia & not reported & 1,100 & $110,000,000$ & & 27 \\
\hline Samoa & not reported & 1,300 & $120,000,000$ & & 32 \\
\hline River & \multicolumn{5}{|r|}{ not assessed } \\
\hline $\begin{array}{l}\text { Total (Wave to EEZ + Tidal + } \\
\text { Ocean Current + Ocean } \\
\text { Thermal + River) }\end{array}$ & & 4,100 & $380,000,000$ & & 98 \\
\hline $\begin{array}{l}\text { Total (Wave to } 10 \mathrm{nmi}+\text { Tidal + } \\
\text { Ocean Current + Ocean } \\
\text { Thermal + River) }\end{array}$ & & 4,100 & $380,000,000$ & & 98 \\
\hline
\end{tabular}

${ }^{a} A l l$ values are listed to two significant figures; therefore, totals shown may not equal the sum of values.

${ }^{b}$ Detailed methodologies for estimating Technical Resource are provided in Section 2.

\subsection{Inland States}

The U.S. inland states' marine energy resources are reported by state and regional totals (Table 10).

Inland U.S. states have $41 \mathrm{TWh} / \mathrm{yr}$ of technical river hydrokinetic resource, equivalent to the power needs of 3.8-million homes and $0.99 \%$ of the total electricity generation by U.S. states in 2019. While each inland state has some river hydrokinetic resource, most of the resource is along the lower Mississippi and Ohio river basins. 
Table 10. Theoretical and Technical River Hydrokinetic Energy Resources in Inland States ${ }^{a}$

\begin{tabular}{|c|c|c|c|c|c|}
\hline & $\begin{array}{r}\text { Theoretical } \\
\text { Resource } \\
(\mathrm{TWh} / \mathrm{yr})\end{array}$ & $\begin{array}{r}\text { Technical } \\
\text { Resource }^{b} \\
(T W h / y r)\end{array}$ & $\begin{array}{r}\text { Technical } \\
\text { Resource as } \\
\text { Potential } \\
\text { Number of } \\
\text { Homes } \\
\text { Powered }\end{array}$ & $\begin{array}{r}\text { Technical } \\
\text { Resource as } \\
\text { Percent of 2019 } \\
\text { Regional } \\
\text { Electricity } \\
\text { Generation } \\
(1901.0 \text { TWh) } \\
(\%)\end{array}$ & $\begin{array}{r}\text { Technical } \\
\text { Resource as } \\
\text { Percent of US } \\
\text { Electricity } \\
\text { Generation } \\
(4126.7 \text { TWh) } \\
(\%)\end{array}$ \\
\hline \multicolumn{6}{|l|}{$\begin{array}{l}\text { Inland States } \\
\text { Marine Energy Resource }\end{array}$} \\
\hline \multicolumn{6}{|l|}{ River } \\
\hline \multicolumn{6}{|l|}{$\begin{array}{r}\text { River Resource by State } \\
\text { Ranked by Technical Resource } \\
\end{array}$} \\
\hline Arkansas & 52 & 10 & 950,000 & 0.53 & 0.25 \\
\hline Missouri & 50 & 7.5 & 710,000 & 0.40 & 0.18 \\
\hline Tennessee & 34 & 5.4 & 500,000 & 0.28 & 0.13 \\
\hline Kentucky & 27 & 4.1 & 390,000 & 0.22 & 0.10 \\
\hline Illinois & 26 & 3.4 & 320,000 & 0.18 & 0.08 \\
\hline Arizona & 53 & 1.3 & 120,000 & 0.07 & 0.03 \\
\hline Montana & 72 & 1.3 & 120,000 & 0.07 & 0.03 \\
\hline Nebraska & 28 & 1.1 & 110,000 & 0.06 & 0.03 \\
\hline Indiana & 10 & 1.0 & 97,000 & 0.05 & 0.02 \\
\hline Idaho & 76 & 0.88 & 83,000 & 0.05 & 0.02 \\
\hline lowa & 10.0 & 0.75 & 70,000 & 0.04 & 0.02 \\
\hline Ohio & 8.5 & 0.59 & 56,000 & 0.03 & 0.01 \\
\hline South Dakota & 7.0 & 0.58 & 54,000 & 0.03 & 0.01 \\
\hline North Dakota & 6.0 & 0.52 & 49,000 & 0.03 & 0.01 \\
\hline Kansas & 17 & 0.51 & 48,000 & 0.03 & 0.01 \\
\hline Pennsylvania & 24 & 0.50 & 47,000 & 0.03 & 0.01 \\
\hline Utah & 24 & 0.40 & 37,000 & 0.02 & 0.01 \\
\hline West Virginia & 17 & 0.32 & 30,000 & 0.02 & 0.01 \\
\hline Oklahoma & 11 & 0.18 & 17,000 & 0.01 & 0.00 \\
\hline Wisconsin & 5.5 & 0.14 & 13,000 & 0.01 & 0.00 \\
\hline Minnesota & 5.4 & 0.10 & 9,500 & 0.01 & 0.00 \\
\hline Nevada & 5.4 & 0.08 & 7,500 & 0.00 & 0.00 \\
\hline Colorado & 32 & 0.06 & 5,200 & 0.00 & 0.00 \\
\hline Wyoming & 27 & 0.03 & 2,800 & 0.00 & 0.00 \\
\hline Vermont & 0.95 & 0.01 & 750 & 0.00 & 0.00 \\
\hline New Mexico & 12 & 0.00 & 9.6 & 0.00 & 0.00 \\
\hline Michigan & 1.3 & 0.00 & 0.24 & 0.00 & 0.00 \\
\hline Total (River) & 640 & 41 & $3,800,000$ & 2.2 & 0.99 \\
\hline
\end{tabular}

${ }^{a}$ All values are listed to two significant figures; therefore, totals shown may not equal the sum of values.

${ }^{b}$ Detailed methodologies for estimating Technical Resource are provided in Section 2. 


\section{Conclusion}

This report provides an overview of the U.S. marine energy resource magnitude and the methods used to estimate them. The total marine energy resource in the 50 states is $2,300 \mathrm{TWh} / \mathrm{yr}$, equivalent to $57 \%$ of the electricity generated by those states in 2019 . The nation's Pacific and Caribbean territories and freely associated states add an additional 4,100 TWh/yr of OTEC resource. These numbers are based on DOE-sponsored marine energy resource assessments published between 2011 and 2013 (Haas et al. 2011; Haas 2013; Jacobson et al. 2012; Jacobson, Hagerman, and Scott 2011; Ascari et al. 2012) and recent updates (Kilcher, Garcia-Medina, and Yang 2021; Kilcher, Haas, and Muscalus 2021) to the resource assessment studies from NREL, Sandia, and PNNL.

This report shows that the nation's marine energy resources are large and geographically diverse. These resources are particularly attractive because early research indicates that they are more predictable than other renewable energy resources, which may be particularly valuable to future energy markets as variable renewables play an increasing role in the nation's energy mix.

However, to realize this future, more work is needed to improve the accuracy of the technical resource estimates presented here. This starts by improving the accuracy and resolution of the underlying resource data sets. Along these lines, DOE has supported the development of a new high-resolution wave resource data set (Yang and Neary 2020). A similar effort is needed for tidal and ocean-current energy. These data sets must be validated with measurements to be reliable, especially in regions where models identify promising sites. Existing public measurements should be used for validation as much as possible but, where existing measurement data is lacking or is of insufficient quality, targeted measurement efforts are needed.

These DOE-sponsored marine energy resource assessments were performed with utility-scale projects in mind. As such, the resource data reported here do not fully capture the many distributed, smaller-scale resources available (which are a major focus of DOE's new Powering the Blue Economy initiative); thus, this summary may represent an underestimate of the total marine energy resource that is potentially available (LiVecchi et al. 2019).

The U.S. wave energy resource is large $(1,400 \mathrm{TWh} / \mathrm{yr})$, and the vast majority of this energy is delivered directly to the nation's shorelines where it can be utilized on land. The U.S. West Coast is a particularly attractive region for wave energy because the resource reaches the shoreline $(240 \mathrm{TWh} / \mathrm{yr})$, where it can be readily utilized. Harnessing $10 \%$ of the West Coast resource $(24 \mathrm{TWh} / \mathrm{yr})$ at a capacity factor of $30 \%$ would require installing approximately $9 \mathrm{GW}^{9}$ of wave energy capacity. Hawaii is also an attractive early market for wave energy $(250 \mathrm{TWh} / \mathrm{yr}$ total and $36 \mathrm{TWh} / \mathrm{yr}$ at $10 \mathrm{nmi}$ ) because it has high energy prices and aggressive renewable portfolio standards. Installing $1 \mathrm{GW}$ of capacity in Hawaii, again assuming a $30 \%$ capacity

\footnotetext{
${ }^{9}$ These discussions of capacity are meant to provide context to the resource estimates so that policymakers, utility operators, and the general public have a better understanding of how and where marine energy might meaningfully contribute to our nation's energy supply. The methodology for estimating capacity is described in Section 2.1.1.
} 
factor, could deliver $27 \%$ of the state's energy needs while harnessing just $7 \%$ of the state's nearland (10 nmi) resource.

Though the nation's tidal energy resource is smaller than the wave resource (220 TWh/yr), the technology is, in general, closer to commercialization. It is also a highly predictable form of renewable energy, and many sites are adjacent to markets that could utilize the power available. Most notable among these sites is Cook Inlet, Alaska, which possesses $36 \%$ of the nation's resource and is adjacent to the state's Railbelt electricity grid that provides power to more than two-thirds of the state's population (Energy Information Administration 2019). Installing $1 \mathrm{GW}$ of tidal energy capacity ${ }^{9}$ in Cook Inlet, at a capacity factor of $30 \%$, would harness just $3 \%$ of the resource and deliver approximately half of the Railbelt's current electricity generation ( $43 \%$ of the state's 2019 generation).

Ocean current energy ( $49 \mathrm{TWh} / \mathrm{yr}$ ) could provide clean reliable power to the Atlantic southeastern states. Florida has a particularly attractive opportunity in the Florida Current, which is part of the Gulf Stream. The Florida Current is attractive because the flow, which squeezes between the coastline around Miami and the shallow shoals of the Bahamas, is both relatively close to shore and highly energetic (depth-averaged current speeds approaching $2 \mathrm{~m} / \mathrm{s}$ ). Installing $1 \mathrm{GW}$ of capacity in the Gulf Stream, at an assumed capacity factor of $70 \%$, would harness $12 \%$ of the resource and power the equivalent of more than 550,000 homes.

Although the OTEC resource is immense $(4,600 \mathrm{TWh} / \mathrm{yr}$ across the United States, its territories, and freely associated states), it is distributed across the nation's vast EEZ. That is, only a very small fraction of this resource (much less than 1\%) is located near land where it can be utilized in the near term. However, if energy storage technologies become sufficiently inexpensive, it does raise the possibility that OTEC - and other marine energy resources that are distant from load centers (e.g., wave energy along Alaska's Aleutian Island chain)—become viable sources of energy. Harnessing $1 \%$ of this resource, assuming a capacity factor of $100 \%$, would mean installing $5.3 \mathrm{GW}$ of OTEC capacity ${ }^{9}$ - energy sufficient to power more than 4-million homes.

The nation's riverine hydrokinetic resource is attractive because it could provide a clean and reliable source of power to communities or other infrastructure along the nation's riverbanks and waterways. This is a particularly interesting opportunity for remote Alaskan communities, many of which are located along rivers and typically rely on expensive diesel to power their electrical grids. The community of Igiugig is testing a river hydrokinetic device to reduce their use of diesel power (U.S. Department of Energy 2019). Furthermore, many of the same technologies that are developed for tidal and ocean-current energy can also be configured to generate power from rivers.

Finally, it is important to keep in mind that-as is the case for other renewable resource typesthe technical and theoretical resource totals for marine energy are much larger than the practical resource:

It is the practical resource that will ultimately determine the potential contribution of an [marine energy] resource to U.S. electricity generation. Site-specific analyses will be needed to identify the constraints and trade-offs necessary to reach the practical resource. (National Research Council 2013) 
Industry leaders and researchers at national laboratories and universities within the marine energy sector have begun the work of site-specific analysis at many early-market sites.

The task of actually developing those plans or quantifying the practical resource in detail is challenging without commercial technologies. This is because regulators and other stakeholders need detailed technology and project plans to understand the risks and impacts to other ocean uses. Having said that, and in lieu of more detailed analysis, we simply note that a practical resource of just $10 \%$ of the estimated technical resource for the 50 states would equate to roughly $5.7 \%$ of the total 2019 U.S. electricity generation - enough to power 22-million homes. Assuming the capacity factor of these installations is between $30 \%$ and $70 \%$, this would mean a total installed marine energy capacity between $40 \mathrm{GW}$ and $90 \mathrm{GW}$.

Marine energy resources are predictable sources of renewable energy. They are distributed broadly across the world's oceans, along its coastlines, and throughout the world's rivers. As the demand for renewable energy technologies continues to grow, marine energy resources have the potential to contribute meaningfully to the U.S. and world energy supply. 


\section{References}

Allahdadi, M. Nabi, Budi Gunawan, Jonathan Lai, Ruoying He, and Vincent S. Neary. 2019. "Development and Validation of a Regional-Scale High-Resolution Unstructured Model for Wave Energy Resource Characterization along the US East Coast." Renewable Energy. 136. 10.1016/j.renene.2019.01.020.

Ascari, Matthew B., Howard P. Hanson, Lynn Rauchenstein, James Van Zwieten, Desikan Bharathan, Donna Heimiller, Nicholas Langle, George N. Scott, James Potemra, N. John Nagurny, and Eugene Jansen. 2012. "Ocean Thermal Extractable Energy Visualization-Final Technical Report on Award DE-EE0002664. October 28, 2012.” United States. https://doi.org/10.2172/1055457.

Bane, John M., Ruoying He, Michael Muglia, Caroline F. Lowcher, Yanlin Gong, and Sara M. Haines. 2017. "Marine Hydrokinetic Energy from Western Boundary Currents." Annual Review of Marine Science 9 (1): 105-23. https://doi.org/10.1146/annurev-marine-010816-060423.

Bedard, Roger, and George Hagerman. 2004. "E2I EPRI Assessment Offshore Wave Energy Conversion Devices.” Electrical Innovation Institute. Washington, D.C. United States.

García-Medina, Gabriel, H. Tuba Özkan-Haller, and Peter Ruggiero. 2014. "Wave Resource Assessment in Oregon and Southwest Washington, USA." Renewable Energy. 64: 203-14. https://doi.org/10.1016/j.renene.2013.11.014.

Garrett, Chris, and Patrick Cummins. 2005. "The power potential of tidal currents in channels." Proceedings of the Royal Society A. 461: 2563-2572.

http://doi.org/10.1098/rspa.2005.1494.

Gunawan, B., V. S. Neary, and J. Colby. 2014. "Tidal Energy Site Resource Assessment in the East River Tidal Strait, near Roosevelt Island, New York, NY (USA)." Renewable Energy 71: 509-517. https://doi.org/10.1016/j.renene.2014.06.002.

Haas, Kevin A., Hermann M. Fritz, Steven P. French, Brennan T. Smith, and Vincent Neary. 2011. "Assessment of Energy Production Potential from Tidal Streams in the United States". United States. https://doi.org/10.2172/1219367.

Haas, Kevin. 2013. "Assessment of Energy Production Potential from Ocean Currents along the United States Coastline.” United States. https://doi.org/10.2172/1093367.

Haas, Kevin, Xiufeng Yang, Vincent Neary, and Budi Gunawan. 2017. "Ocean Current Energy Resource Assessment for the Gulf Stream System: The Florida Current." Marine Renewable Energy. Edited by Zhaoqing Yang and Andrea Copping, 217-36. Cham: Springer International Publishing. https://doi.org/10.1007/978-3-319-53536-4_9.

International Electrotechnical Commission. 2019. "Part 301: Electricity Producing River Energy Converters-River Energy Resource Assessment.” 301. Marine Energy-Wave, Tidal and Other Water Current Converters. 
- 2020. "Part 1: Terminology Edition 2." Technical Specification 62600-1. Marine Energy_-Wave, Tidal and Other Water Current Converters.

Jacobson, Paul, G. Hagerman, and G. Scott. 2011. "Mapping and Assessment of the United States Ocean Wave Energy esource.” Electric Power Research Institute. 1024637.

Jacobson, Paul T., Thomas M. Ravens, Keith W. Cunningham, and George Scott. 2012.

"Assessment and Mapping of the Riverine Hydrokinetic Resource in the Continental United States.” Electric Power Research Institute. 1026880.

Jenne, D. S., Yi-Hsiang Yu, and V. S. Neary. 2015. "Levelized Cost of Energy Analysis of Marine and Hydrokinetic Reference Models: Preprint." United States.

https://www.osti.gov/biblio/1215196.

Kilcher, Levi, and Robert Thresher. 2016. "Marine Hydrokinetic Energy Site Identification and Ranking Methodology Part I: Wave Energy.” United States. https://doi.org/10.2172/1330617.

Kilcher, Levi, Robert Thresher, and Heidi Tinnesand. 2016. "Marine Hydrokinetic Energy Site Identification and Ranking Methodology Part II: Tidal Energy." United States.

https://doi.org/10.2172/1330619.

Kilcher, Levi, Gabriel Garcia-Medina, and Zhaoqing Yang. 2021. “A Scalable Wave Resource Assessment Methodology: Application to U.S. Waters.” Forthcoming.

Kilcher, Levi, Kevin A. Haas, and Alexandra Muscalus. 2021. "Tidal Resource Gaps Analysis." National Renewable Energy Laboratory. Technical Report (forthcoming).

LiVecchi, A., A. Copping, D. Jenne, A. Gorton, R. Preus, G. Gill, R. Robichaud, R. Green, S. Geerlofs, S. Gore, D. Hume, W. McShane, C. Schmaus, and H. Spence. 2019. "Powering the Blue Economy: Exploring Opportunities for Marine Renewable Energy in Maritime Markets." U.S. Department of Energy, Office of Energy Efficiency and Renewable Energy. Washington, D.C. DOE/GO-1020195157. April 2019.

Lopez, Anthony, Billy Roberts, Donna Heimiller, Nate Blair, and Gian Porro. 2012. "U.S. Renewable Energy Technical Potentials: A GIS-Based Analysis.” Renewable Energy, 40.

Lowcher, Caroline F., Michael Muglia, John M. Bane, Ruoying He, Yanlin Gong, and Sara M. Haines. 2017. "Marine Hydrokinetic Energy in the Gulf Stream Off North Carolina: An Assessment Using Observations and Ocean Circulation Models." Marine Renewable Energy. Edited by Zhaoqing Yang and Andrea Copping, 237-58. Cham: Springer International Publishing. https://doi.org/10.1007/978-3-319-53536-4_10.

Minobe, Shoshiro, Akira Kuwano-Yoshida, Nobumasa Komori, Shang-Ping Xie, and Richard Justin Small. 2008. "Influence of the Gulf Stream on the Troposphere." Nature 452: 206-209. https://doi.org/10.1038/nature06690.

Muglia, Michael, Harvey Seim, and Patterson Taylor. 2020. "Gulf Stream Marine Hydrokinetic Energy Off Cape Hatteras, North Carolina.” Marine Technology Society Journal 54 (6): 24-36. 
Musial, Walt, Donna Heimiller, Philipp Beiter, George Scott, and Caroline Draxl. 2016. "2016 Offshore Wind Energy Resource Assessment for the United States.” NREL/TP-5000-66599. https://doi.org/10.2172/1324533.

National Oceanic and Atmospheric Administration. 2019. "What Is the EEZ?" National Ocean Service website. https://oceanservice.noaa.gov/facts/eez.html, 11/13/19.

National Research Council. 2013. "An Evaluation of the U.S. Department of Energy's Marine and Hydrokinetic Resource Assessments." Washington, D.C. The National Academies Press. https://doi.org/10.17226/18278.

Nihous, G. C. April 5, 2005. “An Order-of-Magnitude Estimate of Ocean Thermal Energy Conversion Resources.” ASME. J. Energy Resour. Technol. December 2005; 127(4): 328-333. https://doi.org/10.1115/1.1949624.

Nihous, G. C. July 7, 2006. "A Preliminary Assessment of Ocean Thermal Energy Conversion Resources.” ASME. J. Energy Resour. Technol. March 2007; 129(1): 10-17. https://doi.org/10.1115/1.2424965.

Nunn, A. D., J. P. Harvey, J. R. Britton, P. A. Frear, and I. G. Cowx. 2007. "Fish, Climate and the Gulf Stream: The Influence of Abiotic Factors on the Recruitment Success of Cyprinid Fishes in Lowland Rivers." Freshwater Biology. 52 (8): 1576-1586.

Palter, Jaime B. 2015. "The Role of the Gulf Stream in European Climate." Annual Review of Marine Science. 7: 113-137.

U.S. Congress. 2020. Consolidated Appropriations Act, 2021. $116^{\text {th }}$ Congress. https://www.congress.gov/116/bills/hr133/BILLS-116hr133enr.pdf.

U.S. Department of Energy. September 2015. "Quadrennial Technology Review: An Assessment of Energy Technologies and Research Opportunities." Chapter 4N, Technology Assessments: Marine and Hydrokinetic Power. https://www.energy.gov/sites/prod/files/2015/12/f27/QTR2015-4N-Marine-and-HydrokineticPower.pdf.

U.S. Department of Energy. 2019. "Energy Department Funding Helps Transform Alaskan River into Renewable Energy Source.” August 8, 2019.

https://www.energy.gov/eere/water/articles/energy-department-funding-helps-transform-alaskanriver-renewable-energy-source

U.S. Energy Information Administration. 2019. "Alaska State Profile and Energy Estimates." https://www.eia.gov/state/analysis.php?sid=AK.

U.S. Energy Information Administration. 2020. www.eia.gov/tools/faqs/.

Wang, Taiping, and Zhaoqing Yang. 2017. “A Modeling Study of Tidal Energy Extraction and the Associated Impact on Tidal Circulation in a Multi-Inlet Bay System of Puget Sound." 
Renewable Energy, Wave and Tidal Resource Characterization, 114 (December): 204-14. https://doi.org/10.1016/j.renene.2017.03.049.

Wang, Taiping and Zhaoqing Yang. 2020. "A Tidal Hydrodynamic Model for Cook Inlet, Alaska, to Support Tidal Energy Resource Characterization." J. Mar. Sci. Eng. 8, no. 4: 254. https://doi.org/10.3390/jmse8040254.

Wu, Wei-Cheng, Taiping Wang, Zhaoqing Yang, and Gabriel García-Medina. 2020.

"Development and Validation of a High-Resolution Regional Wave Hindcast Model for U.S. West Coast Wave Resource Characterization.” Renewable Energy. 152 (June): 736-753. https://doi.org/10.1016/j.renene.2020.01.077.

Yang, Zhaoqing. 2020. "High Resolution Ocean Surface Wave Hindcast (U.S. Wave) Data." Edited by Vince Neary. National Renewable Energy Laboratory. Marine and Hydrokinetic Data Repository. https://doi.org/10.15473/1647329.

Yang, Zhaoqing, and Vincent S. Neary. 2020. "High-Resolution Hindcasts for U.S. Wave Energy Resource Characterization.” International Marine Energy Journal 3 (2): 65-71. https://doi.org/10.36688/imej.3.65-71.

Yang, Zhaoqing, Taiping Wang, Ziyu Xiao, Levi Kilcher, Kevin Haas, Huijie Xue, and Xi Feng. 2020. "Modeling Assessment of Tidal Energy Extraction in the Western Passage." J. Mar. Sci. Eng. 8, no. 6: 411. https://doi.org/10.3390/jmse8060411.

Yang, Z., T. Wang, R. Branch, Z. Xiao, and M. Deb. 2021. "Tidal Stream Energy Resource Characterization in the Salish Sea." Renewable Energy. (In revision.) 